J. Dairy Sci. 95:3225-3247

http://dx.doi.org/10.3168/jds.2011-4895

(C) American Dairy Science Association ${ }^{\circledR}, 2012$.

\title{
Effect of fat additions to diets of dairy cattle on milk production and components: A meta-analysis and meta-regression
}

\author{
A. R. Rabiee, ${ }^{\star}$ K. Breinhild, ${ }^{\star}$ W. Scott, ${ }^{*}$ H. M. Golder, ${ }^{\star}$ E. Block, $†$ and I. J. Lean ${ }^{\star 1}$ \\ ${ }^{*}$ SBScibus, PO Box 660, Camden 2570, New South Wales, Australia \\ †Church and Dwight Co. Inc., 469 North Harrison Street, Princeton, NJ 08543
}

\begin{abstract}
The objectives of this study were to critically review randomized controlled trials, and quantify, using metaanalysis and meta-regression, the effects of supplementation with fats on milk production and components by dairy cows. We reviewed 59 papers, of which 38 (containing 86 comparisons) met eligibility criteria. Five groups of fats were evaluated: tallows, calcium salts of palm fat (Megalac, Church and Dwight Co. Inc., Princeton, NJ), oilseeds, prilled fat, and other calcium salts. Milk production responses to fats were significant, and the estimated mean difference was $1.05 \mathrm{~kg} /$ cow per day, but results were heterogeneous. Milk yield increased with increased difference in dry matter intake (DMI) between treatment and control groups, decreased with predicted metabolizable energy (ME) balance between these groups, and decreased with increased difference in soluble protein percentage of the diet between groups. Decreases in DMI were significant for Megalac, oilseeds, and other Ca salts, and approached significance for tallow. Feeding fat for a longer period increased DMI, as did greater differences in the amount of soluble protein percentage of the diet between control and treatment diets. Tallow, oilseeds, and other $\mathrm{Ca}$ salts reduced, whereas Megalac increased, milk fat percentage. Milk fat percentage effects were heterogeneous for fat source. Differences between treatment and control groups in duodenal concentrations of C18:2 and C 18:0 fatty acids and $\mathrm{Mg}$ percentage reduced the milk fat percentage standardized mean difference. Milk fat yield responses to fat treatments were very variable. The other Ca salts substantially decrease, and the Megalac and oilseeds increased, fat yield. Fat yield increased with increased DMI difference between groups and was lower with an increased estimated ME balance between treatment and control groups, indicating increased partitioning of fat to body tissue reserves. Feeding fats decreased milk protein percentage, but results were heterogeneous. An
\end{abstract}

Received September 1, 2011.

Accepted January 8, 2012.

${ }^{1}$ Corresponding author: ianl@sbscibus.com.au increased number of milkings increased the milk protein percentage, whereas the difference between the treatment and control groups in duodenal concentrations of 18:2 fatty acids and dietary $\mathrm{Mg}$ concentration reduced the milk protein percentage. None of the fat treatments influenced milk protein production. The range of responses to different fats fed approached or exceeded 5 standard deviations from the mean and differed in point direction for all variables studied, indicating the varied and profound biological effects of fats. Responses to fat feeding were highly heterogeneous for all variables studied and heterogeneity was present within responses to individual fat groups. The lower DMI combined with higher milk and milk fat production showed that fats could improve the efficiency of milk production. More studies are required to more completely characterize sources of variation in responses to fats.

Key words: dairy cattle, fat, meta-analysis, metaregression

\section{INTRODUCTION}

Feeding fat has been shown to improve milk production, milk fat production, and BCS (Weiss and PinosRodríguez, 2009). Commonly used fat sources include oilseeds, such as whole cottonseed, and full-fat soybeans, animal fats, palm oils, and various modifications to these designed to reduce availability of nutrients to biohydrogenation in the rumen. Kronfeld (1976) proposed that optimal diets contain a mix of glucogenic, aminogenic, and lipogenic precursors for milk production, of which 15 to $25 \%$ of ME intake should be lipids. Palmquist and Jenkins (1980) stated that rations designed for high milk yield should contain supplemental fat to increase energy content in the diet, while maintaining adequate fiber intake for milk fat synthesis. Saturated fatty acids, as found in greater concentrations in tallow, or rumen-protected forms may be particularly useful because these have minimal effects on rumen microbial activity (Palmquist and Jenkins, 1980).

Differences in milk production responses of cattle to different lipids have been observed, and milk fat and protein responses of dairy cows have been variable. Fac- 
tors thought to influence milk production responses include the stage of lactation when supplements are fed, effects of fats on DMI, and supplemental fat sources (Block and Evans, 2010a). Grummer (1988), Jerred et al. (1990), and Simas et al. (1995) all found lower DMI when cows were fed high fat diets immediately after calving.

Sources of fat may influence responses through effects on ruminal fermentation and nutrient digestion. Further, biohydrogenation of fats in the rumen may result in the formation of intermediates, such as trans-10 C18:1 or trans-10,cis-12 C18:2, that are associated with, or have been demonstrated to cause, milk fat depression, (Griinari et al., 1998; Baumgard et al., 2000, 2002; Bauman and Griinari, 2003; Moate et al., 2008). The effects of trans-10,cis-12 18:2 on milk fat synthesis and depression (Bauman and Griinari, 2003) and the role of fats in arachidonic acid metabolism and immune responses (Calder, 2006) indicate that fats are very active biological agents. Wu and Huber (1994), in a quantitative review of responses to milk fats, identified negative effects of fat feeding on milk protein content. Further studies have been conducted since that review and their conclusions can be re-examined using a larger database.

Meta-analysis is a statistical review technique that provides greater statistical power in quantifying the overall production response than individual experimental studies by substantially increasing the sample size studied. Meta-analysis is also, perhaps, the only practical means by which the role of confounding from changes in diet structure when conducting intervention studies can be examined. Confounding of studies results potentially because an increase in the concentration of one dietary nutrient must result in a decreased proportion of other dietary components. Given the potential for carbohydrates, proteins, minerals, and other micronutrients to influence milk production, it is important to examine differences in at least some of these components among treatment and control diets to evaluate whether responses to treatment could have been confounded by these differences.

This study reviewed and collated papers and reports on fat supplementation. Our aim was to quantify the effects of supplementation on milk production and components to improve the precision of point estimates derived from pooled data, answer questions not posed by the individual studies identified by literature search, address controversies arising from apparently conflicting study results, and generate new hypotheses. We also explored sources of heterogeneity among production studies, with the intent of controlling for confounding in studies and evaluated the presence of publication bias in these data.

\section{MATERIALS AND METHODS}

\section{Literature Search}

Our literature search used PubMed, Google Scholar, ScienceDirect, Scirus, and CAB; contact with workers in the field; and investigation of references in papers. It was based on the following key words: days in milk, prepartum, peripartum, postpartum, fat supplementation, tallow, calcium salts of fatty acids, cottonseed, soybean meal, prilled fatty acids, oilseeds, protected fats, cattle, cow, dairy, milk yield, milk composition, and dry matter intake. Although more than 200 papers were identified, only 59 research papers with appropriate study designs had milk production, milk composition, and DMI data. Of these, 38 randomized clinical studies with milk production data, containing 86 comparisons, were used. Seventy-six studies with DMI information that met the selection criteria for a meta-analysis were subsequently evaluated to determine the effect of fat supplementation on DMI. A list of publications reviewed for the study is provided in Table 1.

\section{Inclusion and Exclusion Criteria}

Studies were included or excluded in this study based on a series of criteria developed by the authors. Quality assessment criteria included randomization of study groups, blinding to treatment application and analysis of data, statistical analysis, and comparability of treatment groups at entry to each trial. Trials were included in the analysis if they met the following criteria: full manuscripts from peer-reviewed journals, published after 1980, that evaluated fat supplementation in dairy cattle; had a description of randomization processes; reported the form of fat supplements, including calcium salts of fatty acids, tallows, prilled fats (free fatty acids), oilseeds (e.g., whole cottonseed and soybean products and, in one case, with free oil); were not fishmeal or fish oil only supplements; animals studied were lactating dairy cows; the paper contained sufficient data to determine the effect size for production outcomes (e.g., the number of cows in each treatment and control group); a measure of effect amendable to effect size analysis for continuous data (e.g., standardized mean difference, SMD); a measure of variance (SE or SD) or $P$-value for each effect estimate or treatment and control comparisons. Effect size is the standardized difference between treatment and control groups means using the standard deviations of control and treatment groups.

Twenty-one studies were excluded from analysis. Studies that failed to meet the essential criteria of the randomized controlled trial included reviews and 
studies that had no milk production data or had other supplementary treatments. Crossover and Latin square studies were also excluded a priori from the meta-analysis because of the potential for these to have carryover effects (Lean et al., 2009).

\section{Data Extraction}

The data extracted included journal, year of publication, country or state, authors, trial design, length of trial feeding period, number of cows in control and treatment groups, milk production ( $\mathrm{kg} / \mathrm{cow}$ per d), $3.5 \% \mathrm{FCM}(\mathrm{kg} /$ cow per d), ECM ( $\mathrm{kg} /$ cow per d), milk fat percentage (\%) and yield ( $\mathrm{kg} / \mathrm{cow}$ per $\mathrm{d})$, milk protein percentage (\%) and yield ( $\mathrm{kg} / \mathrm{cow}$ per $\mathrm{d})$, measures of variance of responses (SE or $\mathrm{SD}$ ), and $P$-values. Other information extracted from relevant papers were duration of treatment before and after calving, parity, breed, number of milkings per day, use of bST, type and amount of fat supplement, and types of diets. A summary of studies and variables measured is in Table 1 .

\section{Diet Information and CPM-Dairy}

Diets provided in the eligible reviewed papers were extracted (Table 2). These data were initially entered into a spreadsheet (Excel, Microsoft Corp., Redmond, WA) and subsequently into CPM-Dairy (version 3.08; Cornell-Penn-Miner, http://cahpwww.vet.upenn.edu/ node/77). A standard operating procedure was developed for the procedures used (Appendix). Briefly, each paper was examined to determine if each of the following essential inputs for compiling a ration in CPMDairy were described: animal details, diet ingredients, daily DMI of the described ingredients, composition of individual feed ingredients, and housing (i.e., grazing, feedlot, dry lot). Information on animal, housing, and environment were then entered in CPM-Dairy for each diet. We noted which details were described in the paper and which required assumptions. The feed ingredients that were described in the paper were selected from the CPM-Dairy Feedbank library (http:// cahpwww.vet.upenn.edu/node/83), and the individual feed components were edited to the specifications as described in the paper. The average DIM was considered as the mean for the period of the trial. The intake of each feed ingredient was entered in CPM-Dairy as described in the paper. When a paper had insufficient information on total DMI or when cows were grazed, the CPM-Dairy model-estimated DMI was used. Estimated diets were cross-validated between information provided in the papers and that from the CPM-Dairy Feedbank library.

\section{Statistical Analysis}

We used Stata (Intercooled Stata v.11, StataCorp. LP, College Station, TX) to analyze production and DMI data by SMD, which is also called effect size analysis, in which the difference between treatment and control groups means was standardized using the standard deviations of control and treatment groups. The SMD estimates were pooled using the methods of Cohen (1988) for the fixed effect model, and DerSimonian and Laird (1986) for the random effects model. If the paper reported separate estimates of measure of variance (SE or SD) for each group, these were recorded as such. If a study reported a common SE or SD, the estimate was used for both control and treatment groups. If a study only reported a $z$-statistic or $P$-value, estimates of SE or SD were computed using the number of cows in each group. For studies that only reported a $P$-value less than or equal to a given value (e.g., $P \leq 0.05$ ), then the given value was used and $P$-value and $\mathrm{SE}$ were computed using a similar method to that described above. For studies that only reported a nonsignificant effect, $P$-values of $0.15,0.3$, and 0.5 were assigned and compared as described by Sanchez et al. (2004). The $P$-value that produced the smallest estimate of overall SMD was selected for the calculation of the standard error. Fixed and random effects models were conducted for each production outcome to estimate the effect size, 95\% CI, and statistical significance of SMD. We recognize that a clustering effect results from multiple comparisons to a single control group but have determined that the variance inflation effect will be minor unless the number of repeated comparisons is very large. The statistical methods of meta-analytic procedures that were used in this paper have been previously published by the authors of this study (Lean et al., 2009).

Forest Plots. The effects of fat supplements on production performance of lactating dairy cows are displayed in forest plots, using the estimated SMD of fat products (Figure 1). Points to the left of the line represent a reduction in the outcome, whereas points to the right of the line indicate an increase in the variable. Each square represents the mean effect size for that study. The upper and lower limits of the line connected to the square represent the upper and lower 95\% CI for the effect size. Weight is estimated by the inverse of the variance of the effect size. Box sizes are proportional to the inverse variance of the estimates. The size of the square box reflects the relative weighting of the study to the overall effect size estimate with larger squares representing greater weight. Boxes draw attention to the studies with the greatest weight. The gray vertical line represents the mean difference of zero or no effect. 


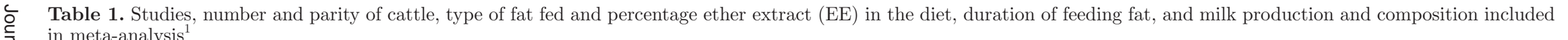
in meta-analysis

\begin{tabular}{|c|c|c|c|c|c|c|c|}
\hline \multirow[b]{2}{*}{ Study } & \multirow[b]{2}{*}{$\begin{array}{l}\text { No. } \\
(\mathrm{MP} / \mathrm{PP})^{2}\end{array}$} & \multicolumn{2}{|c|}{ Type of fat fed ${ }^{3}$ (\% EE) } & \multirow{2}{*}{$\begin{array}{l}\text { Start of treatment } \\
\text { (duration of } \\
\text { fat feeding) }\end{array}$} & \multicolumn{3}{|c|}{ Results for control, treatment } \\
\hline & & Control & Treatment & & $\begin{array}{l}\text { Milk production } \\
(\mathrm{L} / \mathrm{d})\end{array}$ & $\begin{array}{l}\text { Milk fat } \\
(\%)\end{array}$ & $\begin{array}{l}\text { Milk protein } \\
(\%)\end{array}$ \\
\hline \multirow{2}{*}{$\begin{array}{l}\text { Maiga and Schingoethe } \\
\text { (1997) }\end{array}$} & $40(24 / 16)$ & 1. Bypass protein $(2.9 \%)$ & 1. Tallow $(5.6 \%)$ & Wk 4 postpartum (13 wk) & $32.8,36.4$ & $3.55,3.39$ & $2.98,2.85$ \\
\hline & & $\begin{array}{l}\text { 2. Bypass protein }+ \\
\text { molasses }(2.7 \%)\end{array}$ & 2. Tallow $(5.3 \%)$ & & $35.9,33.6$ & $3.46,3.44$ & $2.97,2.82$ \\
\hline \multirow{2}{*}{$\begin{array}{l}\text { Bertrand and Grimes } \\
(1997)\end{array}$} & $28(28 / 0)$ & 1. SBM $(2.4 \%)$ & 1. Tallow $(8.3 \%)$ & Not stated; average & $30.4,26.9$ & $3.63,3.12$ & $3.69,3.52$ \\
\hline & & 2. $\mathrm{SBM}+$ yeast $(2.4 \%)$ & 2. Tallow + yeast $(8.3 \%)$ & DIM 98 d $(84$ d) & $30.6,27.2$ & $3.44,3.19$ & $3.43,3.50$ \\
\hline \multirow[t]{2}{*}{ Markus et al. (1996) } & $33(21 / 12)$ & $1+2$. Basal diet $(1.8 \%)$ & $\begin{array}{l}\text { 1. Whole sunflower } \\
\text { seed }(4.2 \%)\end{array}$ & $\begin{array}{l}\text { Not stated: average } \\
16 \text { DIM }(16 \mathrm{wk})\end{array}$ & $34.4,34.6$ & $3.2,3.1$ & $3.1,3.0$ \\
\hline & & & 2. Tallow $(4.1 \%)$ & & $34.4,35.5$ & $3.2,3.3$ & $3.1,3.0$ \\
\hline Maiga et al. (1995) & $20(6 / 14)$ & 1. $\operatorname{SBM}(2.9 \%)$ & 1. Tallow $(4.8 \%)$ & Wk 4 postpartum (13 wk) & $31.9,33.7$ & $3.48,3.65$ & $3.00,2.98$ \\
\hline \multirow[t]{3}{*}{ Wu et al. (1993) } & $24(16 / 8)$ & $\begin{array}{l}1+2+3 . \mathrm{WCS} \\
+\operatorname{SBM}(3.7 \%)\end{array}$ & 1. Tallow $(6.2 \%)$ & $\begin{array}{l}\text { Not stated; average } \\
\text { DIM } 92 \mathrm{~d}(72 \mathrm{~d})\end{array}$ & $31.6,33.9$ & $3.25,3.26$ & $3.13,3.05$ \\
\hline & & & $\begin{array}{l}\text { 2. Ca salt of palm } \\
\text { fatty acid }(6.1 \%)\end{array}$ & & $31.6,32.9$ & $3.25,3.36$ & $3.13,2.97$ \\
\hline & & & 3. Prilled fat $(6.2 \%)$ & & $31.6,34.2$ & $3.25,3.38$ & $3.13,3.01$ \\
\hline \multirow[t]{3}{*}{ Pires et al. (1996) } & $36(36 / 0)$ & $1+2+3 . \mathrm{SBM}(3.02 \%)$ & $\begin{array}{l}\text { 1. Ground roasted } \\
\text { soybeans }(6.09 \%)\end{array}$ & Wk 3 postpartum (16 wk) & $39.6,40.7$ & $3.33,3.09$ & $3.03,2.83$ \\
\hline & & & $\begin{array}{l}2 . \text { Whole roasted } \\
\text { soybeans }(6.00 \%)\end{array}$ & & $39.6,36.4$ & $3.33,3.50$ & $3.03,2.88$ \\
\hline & & & 3. Tallow $(5.84 \%)$ & & $39.6,39.3$ & $3.33,3.29$ & $3.03,2.98$ \\
\hline Jenkins et al. (1998) & $36(24 / 12)$ & 1. SBM $(1.85 \%)$ & 1. Tallow $(7.1 \%)$ & $\begin{array}{l}\text { Cows between } 20 \text { and } 80 \text { DIM; } \\
\text { average DIM } 44 \mathrm{~d}(18 \mathrm{wk})\end{array}$ & $33.25,36.55$ & $3.39,3.20$ & $3.12,2.98$ \\
\hline \multirow[t]{2}{*}{ Hoffman et al. (1991) } & $48(32 / 16)$ & 1. Solvent SBM (3.1\%) & 1. Tallow $(5.7 \%)$ & d postpartum $(128 \mathrm{~d})$ & $31.8,33.1$ & $3.67,3.60$ & $3.14,3.04$ \\
\hline & & 2. Expeller SBM (3.3\%) & 2. Tallow $(6.0 \%)$ & & $31.6,32.7$ & $3.63,3.82$ & $3.03,3.00$ \\
\hline \multirow[t]{2}{*}{ Erickson et al. $(1992)^{4}$} & $40(40 / 0)$ & 1. SBM $(2.9 \%)$ & 1. Ca-LCFA (5.4\%) & d 15 postpartum $(83 \mathrm{~d})$ & $36.2,38.2$ & $3.32,3.36$ & $2.71,2.55$ \\
\hline & & $\begin{array}{l}\text { 2. SBM + nicotinic } \\
\text { acid }(2.9 \%)\end{array}$ & $\begin{array}{l}\text { 2. Ca-LCFA + } \\
\text { nicotinic acid }(5.4 \%)\end{array}$ & & $36.4,39.3$ & $3.32,3.35$ & $2.84,2.68$ \\
\hline Spicer et al. $(1993)^{4}$ & $14(14 / 0)$ & 1. WCS + SBM $(6.0 \%)$ & 1. Ca-LCFA $(7.4 \%)$ & d 0 postpartum $(84 \mathrm{~d})$ & $36.9,36.0$ & $3.54,3.44$ & $\begin{array}{l}\text { Not given } \\
\text { (assumed } 3.0 \% \\
\text { protein for CPM } \\
\text { calculation) }\end{array}$ \\
\hline \multirow[t]{2}{*}{ Simas et al. (1995) } & $36(24 / 12)$ & $\begin{array}{l}\text { 1. Dry-rolled } \\
\text { sorghum }(5.7 \%)\end{array}$ & 1. Ca-LCFA (7.5\%) & Starting d 5 postpartum $(91 \mathrm{~d})$ & $34.3,33.4$ & $3.16,3.23$ & $2.93,2.79$ \\
\hline & & $\begin{array}{l}\text { 2.Steam-flaked } \\
\text { sorghum }(5.7 \%)\end{array}$ & 2. Ca-LCFA $(7.5 \%)$ & & $39.3,36.5$ & $2.91,3.05$ & $3.00,2.99$ \\
\hline \multirow[t]{5}{*}{ Harrison et al. (1995) } & $108(72 / 36)$ & \multicolumn{2}{|c|}{ Herd 1 multiparous: } & Herd 1: wk 3 postpartum (15 & \multicolumn{3}{|c|}{ Herd 1 (3-17 wk) } \\
\hline & & 1. Concentrate $(2.5 \%)$ & $\begin{array}{l}\text { 1. WCS + Ca- } \\
\text { LCFA }(6.0 \%)\end{array}$ & $\begin{array}{l}\text { wk); wk } 18 \text { postpartum ( } 27 \\
\text { wk); Herd } 2: \text { wk } 3 \text { postpartum } \\
(13 \text { wk); wk } 16 \text { postpartum } \\
(28 \text { wk) for both primiparous } \\
\text { and multiparous cows }\end{array}$ & $43.13,41.0$ & $3.24,3.74$ & $3.08,2.91$ \\
\hline & & & & & \multicolumn{2}{|c|}{ Herd 1 (18-44 wk) } & $3.07,2.91$ \\
\hline & & 2. $\operatorname{WCS}(4.4 \%)$ & 2. WCS + Ca- & & $31.50,33.13$ & $3.50,3.46$ & $3.36,3.14$ \\
\hline & & & LCFA $(6.0 \%)$ & & $32.88,33.13$ & $3.46,3.46$ & $3.29,3.14$ \\
\hline
\end{tabular}


Table 1 (Continued). Studies, number and parity of cattle, type of fat fed and percentage ether extract (EE) in the diet, duration of feeding fat, and milk production and composition included in meta-analysis ${ }^{1}$

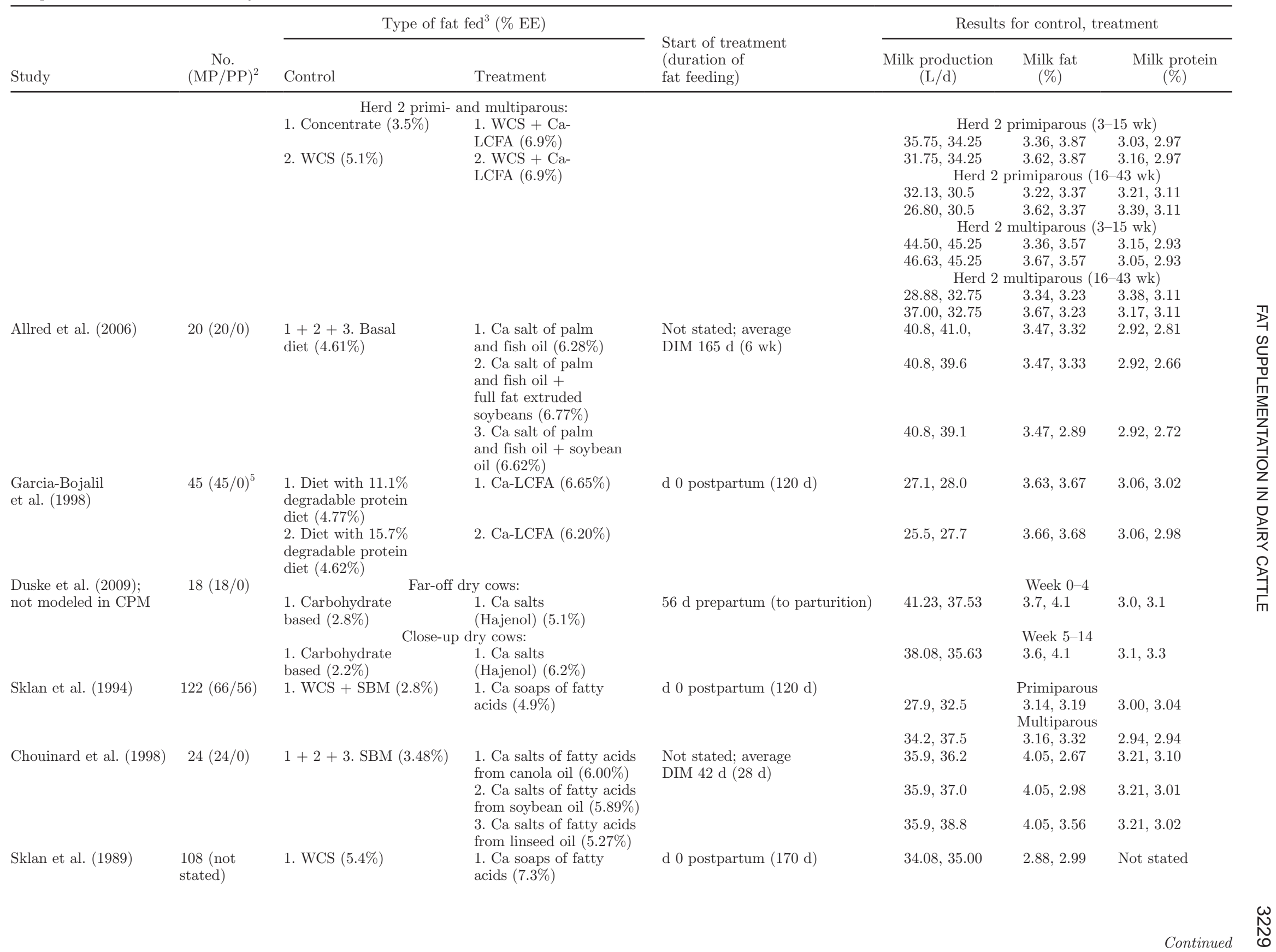


c Table 1 (Continued). Studies, number and parity of cattle, type of fat fed and percentage ether extract (EE) in the diet, duration of feeding fat, and milk production and composition included in meta-analysis

Type of fat fed ${ }^{3}(\% \mathrm{EE})$

\begin{tabular}{|c|c|c|}
\hline Study & $\begin{array}{c}\text { No. } \\
(\mathrm{MP} / \mathrm{PP})^{2}\end{array}$ & Control \\
\hline Lubis et al. $(1990)^{4}$ & $\begin{array}{l}331 \text { (not } \\
\text { stated) }\end{array}$ & $\begin{array}{l}\text { 1. } \operatorname{WCS}(5.1 \% \text {; trial } 1) \\
\text { 2. } \operatorname{WCS}(5.5 \% \text {; trial } 2)\end{array}$ \\
\hline Driver et al. (1990) & $20(20 / 0)$ & $\begin{array}{l}\text { 1. Heat-treated } \\
\text { SBM }(3.6 \%)\end{array}$ \\
\hline Dhiman et al. (1999) & $\begin{array}{l}24 \text { (not } \\
\text { stated) }\end{array}$ & $1+2 . \operatorname{SBM}(2.73 \%)$ \\
\hline Kim et al. (1993) & $\begin{array}{l}33 \text { (not } \\
\text { stated) }\end{array}$ & $1+2 . \operatorname{SBM}(2.5 \%)$ \\
\hline Faldet and Satter (1991) & $46(46 / 0)$ & $1+2 . \operatorname{SBM}(3.3 \%)$ \\
\hline Casper et al. (1990) & $40(24 / 16)$ & 1. Corn + SBM $(2.5 \%)$ \\
\hline & & $\begin{array}{l}\text { 2. Dried whey }+ \\
\operatorname{SBM}(2.1 \%)\end{array}$ \\
\hline $\begin{array}{l}\text { Khorasani and } \\
\text { Kennelly (1998) }\end{array}$ & $25(20 / 5)$ & $\begin{array}{l}1+2+3+4 . \text { Basal } \\
\operatorname{diet}(\mathrm{EE}=2.75 \%)\end{array}$ \\
\hline
\end{tabular}
$\operatorname{diet}(\mathrm{EE}=2.75 \%)$ (5.6\%)

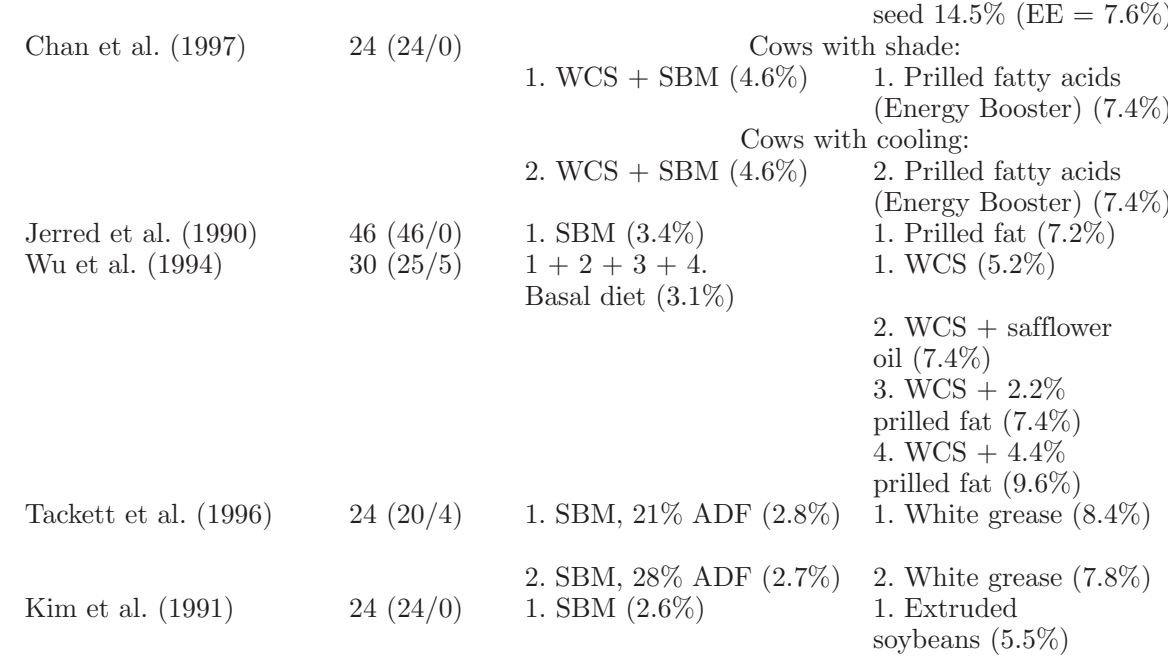

Results for control, treatment

Start of treatment (duration of fat feeding)

Trial 1: not stated, average DIM $215 \mathrm{~d}(60 \mathrm{~d})$; trial 2: not stated, average DIM $93 \mathrm{~d}(90 \mathrm{~d})$

d 10 prepartum $(115 \mathrm{~d})$

2. Ca-LCFA
(7.2\%; trial 2$)$

1. Heat-treated whole soybeans $(6.3 \%)$

1. Full-fat extruded soybean $(4.89 \%)$ 2. Full-fat extruded cottonseed $(4.56 \%)$

1. Extruded soybeans $(5.1 \%)$ 2. Ca-LCFA (3.0\%) 1. Raw soybeans $(5.6 \%)$ 2. Heated soybeans

1. Corn + extruded soybean $(5.2 \%)$

2. Dried whey +

extruded soybean $(4.7 \%)$

1. Jet-Sploded canola seed $3.75 \%(\mathrm{EE}=4.0 \%)$ 2. Jet-Sploded canola seed $7.5 \%(\mathrm{EE}=5.13 \%)$

3. Jet-Sploded canola

Not stated; average

DIM 108 d (8 wk)

wk 4 postpartum (12 wk)

d 15 postpartum (104 d)

wk 4 postpartum (13 wk)

Not stated; average

DIM 123 d (70 d)

Not stated; average

DIM 80 d (56 d)

\begin{tabular}{|c|c|c|}
\hline $\begin{array}{l}\text { Milk production } \\
(\mathrm{L} / \mathrm{d})\end{array}$ & $\begin{array}{l}\text { Milk fat } \\
(\%)\end{array}$ & $\begin{array}{c}\text { Milk protein } \\
(\%)\end{array}$ \\
\hline $20.4,20.6$ & $3.58,3.60$ & $3.05,3.08$ \\
\hline $34.3,34.4$ & $3.26,3.21$ & $2.98,2.99$ \\
\hline $38.5,38.5$ & $3.53,3.38$ & $2.84,2.66$ \\
\hline $30.9,39.2$ & $3.61,3.18$ & $3.25,2.98$ \\
\hline $30.9,36.6$ & $3.61,3.31$ & $3.25,3.00$ \\
\hline $29.2,32.4$ & $3.20,2.69$ & $2.99,2.93$ \\
\hline $29.2,31.8$ & $3.20,3.47$ & $2.99,2.81$ \\
\hline $34.5,34.2$ & $3.41,3.50$ & $2.99,2.89$ \\
\hline $34.5,38.9$ & $3.41,3.41$ & $2.99,2.85$ \\
\hline $31.7,33.8$ & $3.24,3.05$ & $3.03,2.94$ \\
\hline $31.8,35.3$ & $3.29,2.91$ & $3.03,2.96$ \\
\hline $25.3,23.5$ & $3.41,3.36$ & $3.11,3.14$ \\
\hline $25.2,25.1$ & $3.41,3.53$ & $3.11,3.06$ \\
\hline $25.2,24.0$ & $3.41,3.38$ & $3.11,3.01$ \\
\hline $25.2,25.8$ & $3.41,3.33$ & $3.11,2.97$ \\
\hline $29.5,30.0$ & $2.93,3.23$ & $2.99,2.95$ \\
\hline $31.0,31.7$ & $3.25,3.13$ & $2.90,2.94$ \\
\hline $39.2,38.8$ & $3.57,3.88$ & $2.89,2.87$ \\
\hline $32.5,32.6$ & $3.49,3.48$ & $3.20,3.03$ \\
\hline $32.5,35.0$ & $3.49,3.26$ & $3.20,3.03$ \\
\hline $32.5,34.3$ & $3.49,3.58$ & $3.20,3.08$ \\
\hline $32.5,33.0$ & $3.49,3.51$ & $3.20,3.07$ \\
\hline $37.5,38.9$ & $3.4,2.9$ & $3.5,3.3$ \\
\hline $34.7,38.0$ & $3.5,3.2$ & $3.4,3.1$ \\
\hline $33.0,35.8$ & $3.2,2.88$ & $2.92,2.88$ \\
\hline
\end{tabular}

5 d postpartum $(100 \mathrm{~d})$

Not stated; average

DIM 50 d (75 d)

Not stated; average

DIM $32 \mathrm{~d}(12 \mathrm{wk})$

wk 4 postpartum (13 wk) 
Table 1 (Continued). Studies, number and parity of cattle, type of fat fed and percentage ether extract (EE) in the diet, duration of feeding fat, and milk production and composition included in meta-analysis ${ }^{1}$

\begin{tabular}{|c|c|c|c|c|c|c|c|}
\hline \multirow[b]{2}{*}{ Study } & \multirow[b]{2}{*}{$\begin{array}{c}\text { No. } \\
(\mathrm{MP} / \mathrm{PP})^{2}\end{array}$} & \multicolumn{2}{|c|}{ Type of fat fed ${ }^{3}(\%$ EE) } & \multirow{2}{*}{$\begin{array}{l}\text { Start of treatment } \\
\text { (duration of } \\
\text { fat feeding) }\end{array}$} & \multicolumn{3}{|c|}{ Results for control, treatment } \\
\hline & & Control & Treatment & & $\begin{array}{l}\text { Milk production } \\
(\mathrm{L} / \mathrm{d})\end{array}$ & $\begin{array}{l}\text { Milk fat } \\
(\%)\end{array}$ & $\begin{array}{l}\text { Milk protein } \\
(\%)\end{array}$ \\
\hline \multirow[t]{2}{*}{ Schneider et al. (1988) } & $108(80 / 28)$ & 1. WCS $(4.5 \%)$ & $\begin{array}{l}\text { 1. Ca salts of palm oil } \\
\text { fatty acids (control + } \\
0.5 \mathrm{~kg} \text { of Ca-LCFA) }\end{array}$ & $\begin{array}{l}\text { Cows }<30 \text { or at } \\
\text { parturition }(310 \mathrm{~d})\end{array}$ & $\begin{array}{c}30.8,31.5 \\
\text { (primiparous) }\end{array}$ & $\begin{array}{c}2.7,2.9 \\
\text { (primiparous) }\end{array}$ & Not stated \\
\hline & & & & & $\begin{array}{c}35.8,37.6 \\
\text { (multiparous) }\end{array}$ & $\begin{array}{c}2.8,3.0 \\
\text { (multiparous) }\end{array}$ & \\
\hline \multirow[t]{2}{*}{ Holter et al. (1992) } & $107(107 / 0)$ & $1+2$. Basal diet $(4.07 \%)$ & 1. WCS $(6.70 \%)$ & d 0 postpartum $(112 \mathrm{~d})$ & $35.2,29.6$ & $3.32,4.14$ & $2.86,2.88$ \\
\hline & & & $\begin{array}{l}\text { 2. WCS + Ca- } \\
\text { LCFA }(8.63 \%)\end{array}$ & & $35.2,32.5$ & $3.32,3.89$ & $2.86,2.82$ \\
\hline $\begin{array}{l}\text { Drackley and } \\
\text { Schingoethe (1986) }\end{array}$ & $30(24 / 6)$ & 1. SBM $(2.6 \%)$ & $\begin{array}{l}\text { 1. Extruded SBM } \\
+ \text { whole sunflower } \\
\text { seeds }(6.0 \%)\end{array}$ & wk 4 postpartum (12 wk) & $33.6,33.8$ & $3.55,3.30$ & $2.91,2.74$ \\
\hline \multirow[t]{2}{*}{ Schingoethe et al. (1988) } & $\begin{array}{l}\text { Not stated } \\
\text { for this part } \\
\text { of trial }\end{array}$ & $1+2 . \operatorname{SBM}(2.1 \%)$ & $\begin{array}{l}\text { 1. Heat-treated } \\
\text { SBM }(2.8 \%)\end{array}$ & wk 4 postpartum (13 wk) & $32.2,34.5$ & $2.98,2.89$ & $2.99,2.90$ \\
\hline & & & $\begin{array}{l}\text { 2. Extruded } \\
\text { soybeans }(3.5 \%)\end{array}$ & & $32.2,36.2$ & $2.98,2.63$ & $2.00,2.85$ \\
\hline \multirow[t]{2}{*}{ Finn et al. (1985) } & $30(24 / 6)$ & $\begin{array}{l}1+2 . \text { Corn }+ \\
\operatorname{SBM}(3.0 \%)\end{array}$ & $\begin{array}{l}\text { 1. Whole rolled } \\
\text { sunflower seed }(6.6 \%)\end{array}$ & $21 \mathrm{~d}$ postpartum $(99 \mathrm{~d})$ & $32.2,32.0$ & $3.57,3.18$ & $3.01,2.97$ \\
\hline & & & $\begin{array}{l}\text { 2. Whole rolled sunflower } \\
\text { seed + limestone }(5.9 \%)\end{array}$ & & $32.2,32.8$ & $3.57,3.51$ & $3.01,2.90$ \\
\hline \multirow[t]{6}{*}{ Chounard et al. (1997) } & $24(24 / 0)$ & Pha & se & Not stated; average & & Phase 1 (wk 4) & \\
\hline & & $\begin{array}{l}1+2 . \text { Corn }+ \\
\text { SBM }(3.9 \%)\end{array}$ & $\begin{array}{l}\text { 1. Ca salts }(2 \%) \text { of canola } \\
\text { oil fatty acids }(5.5 \%)\end{array}$ & DIM 39 d (8 wk) & $33.5,35.2$ & $3.55,3.38$ & $2.96,2.80$ \\
\hline & & & $\begin{array}{l}\text { 2. Ca salts }(4 \%) \text { of canola } \\
\text { oil fatty acids }(6.6 \%)\end{array}$ & & $33.5,32.8$ & $3.55,3.29$ & $2.96,2.66$ \\
\hline & & Pha & s: 2 : & & & Phase 2 (wk 8) & \\
\hline & & $\begin{array}{l}1+2 . \text { Corn }+ \\
\operatorname{SBM}(4.0 \%)\end{array}$ & $\begin{array}{l}\text { 1. Ca salts }(2 \%) \text { of canola } \\
\text { oil fatty acids }(5.8 \%)\end{array}$ & & $33.6,35.9$ & $3.41,3.08$ & $3.10,2.96$ \\
\hline & & & $\begin{array}{l}\text { 2. Ca salts }(4 \%) \text { of canola } \\
\text { oil fatty acids }(7.5 \%)\end{array}$ & & $33.6,34.0$ & $3.41,2.93$ & $3.19,2.82$ \\
\hline \multirow[t]{2}{*}{ Petit (2002) } & $90(72 / 18)$ & $\begin{array}{l}1+2 . \text { Barley }+ \text { whole } \\
\text { flaxseed }(8.1 \%)\end{array}$ & 1. Ca-LCFA $(6.6 \%)$ & d 0 postpartum (16 wk) & $35.7,33.5$ & $3.81,4.14$ & $2.98,2.86$ \\
\hline & & & $\begin{array}{l}\text { 2. Micronized } \\
\text { soybeans }(7.0 \%)\end{array}$ & & $35.7,34.4$ & $3.81,3.70$ & $2.98,2.87$ \\
\hline \multicolumn{8}{|c|}{${ }^{1}$ All studies used Holstein except for those of Sklan et al. (1994), Sklan et al. (1989), and Schn } \\
\hline \multicolumn{8}{|c|}{$\begin{array}{l}{ }^{3} \mathrm{SBM}=\text { soybean meal; WCS }=\text { whole cottonseed; Ca-LCFA = calcium salt of long-chain fatty acids (Megalac, Church and Dwight Co. Inc., Princeton, NJ); Ca salts Hajenol = } \\
\text { rumen-protected fat (Harles und Jentzsch GmbH, Uetersen, Germany); Jet-Sploded whole canola seed (Simons Feed Co., Quimby, IA); prilled fatty acids Energy Booster-100 (Mill } \\
\text { Specialties Co., Dundee, IL). }\end{array}$} \\
\hline \multicolumn{8}{|c|}{${ }^{4} \mathrm{EE}$ data obtained from CPM-Dairy outputs. } \\
\hline \multicolumn{8}{|c|}{${ }^{5}$ Second lactation $\mathrm{n}=25$; third lactation $\mathrm{n}=16$; fourth lactation $\mathrm{n}=4$. } \\
\hline
\end{tabular}


Table 2. Predicted estimated average $( \pm \mathrm{SD})$ differences from the control group in CPM-Dairy outputs of diet composition for cows supplemented with different fat products

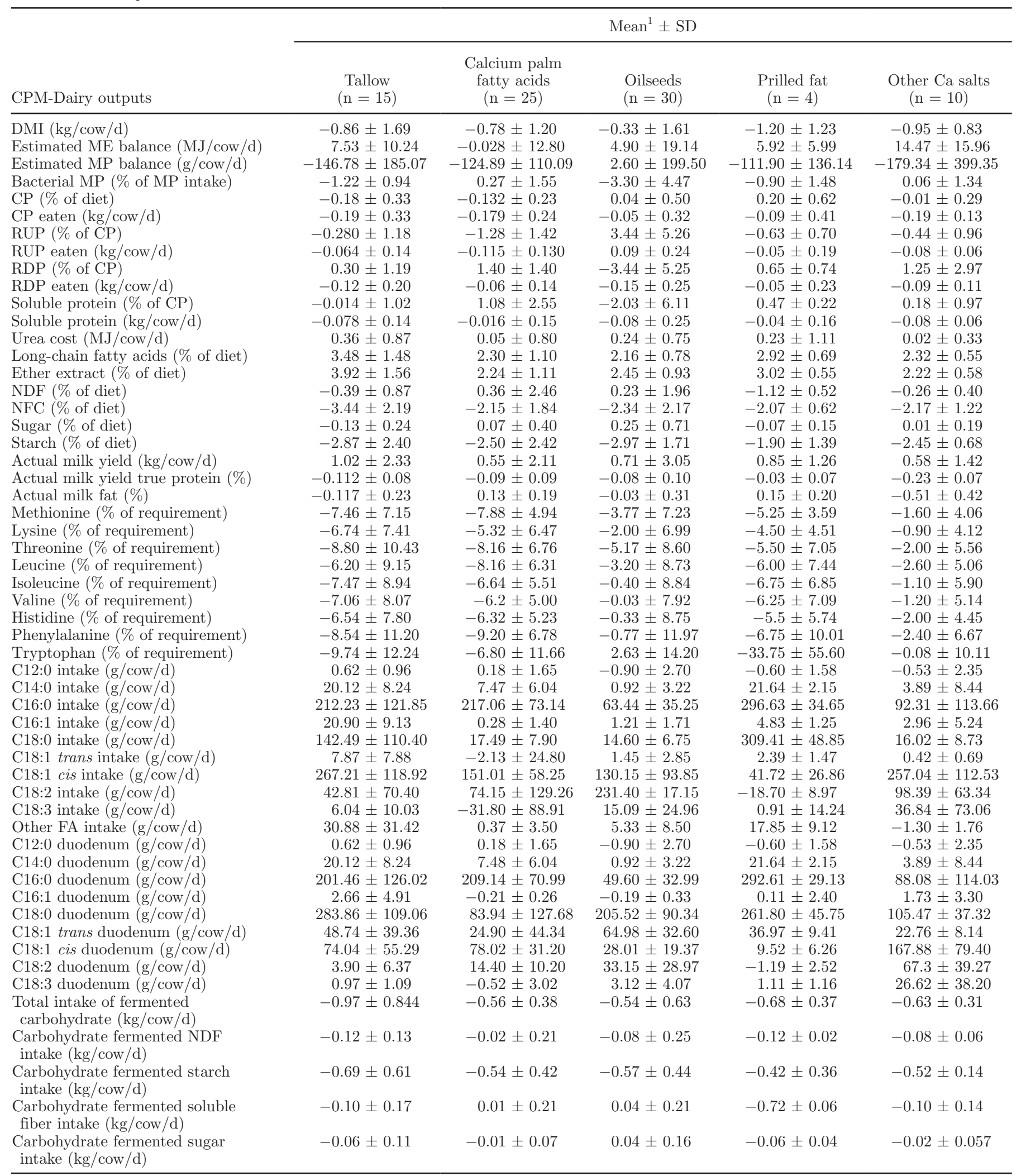

${ }^{1}$ Estimated average results are rounded. 

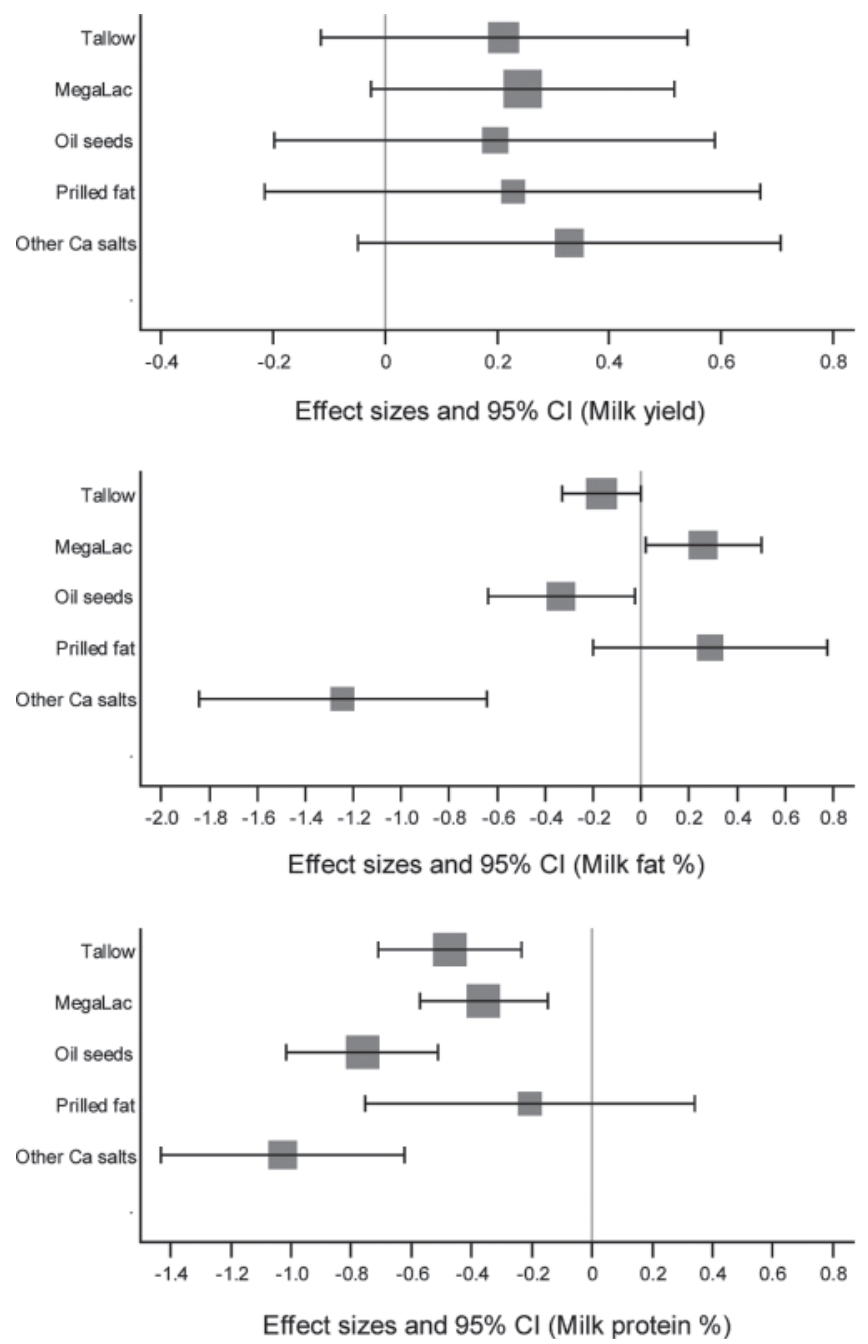
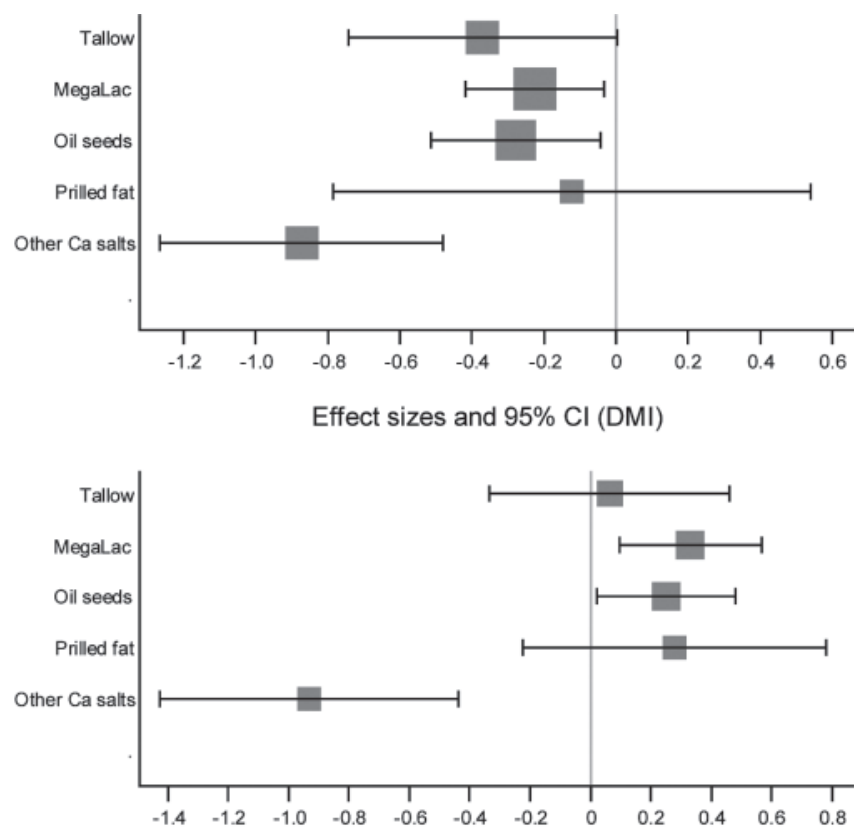

Effect sizes and $95 \% \mathrm{Cl}$ (Milk fat yield)

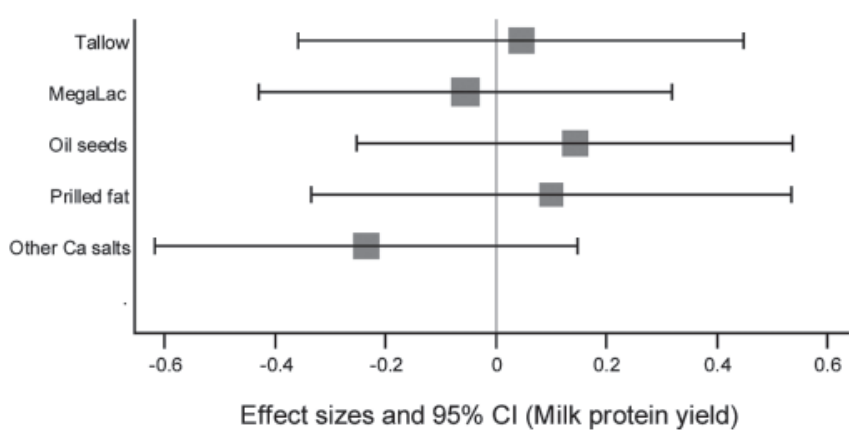

Figure 1. Forest plot of standardized mean difference (SMD), a random effects approach using the method of DerSimonian and Laird (1986), and their 95\% CI and weights for individual fat products [tallow, Megalac (Church and Dwight Co. Inc., Princeton, NJ), oilseeds, prilled fat, and other Ca salts] determined from the results of 86 comparisons of production data of cows supplemented with fat. Box sizes are proportional to the inverse variance of the estimates. The solid vertical gray line represents a mean difference of zero or no effect. Effect sizes are standardized mean differences (standardized using the z-statistic). Thus, points to the left of the line represent a reduction in the parameter, whereas points to the right of the line indicate an increase. Each square represents the mean effect size for that fat product. The upper and lower limit of the line connected to the square represents the upper and lower $95 \%$ CI for the effect size. The size of the square reflects the relative weighting of the fat products to the overall effect size estimate with larger squares representing greater weight.

The estimated SMD results were converted to a measurable unit by multiplying the pooled SMD with the relevant pooled SD for each outcome (http://www. cochrane.org/cochrane-reviews).

Assessment of Heterogeneity. Variations among the trial-level SMD were assessed using $\chi^{2}(\mathrm{Q})$ test of heterogeneity. Heterogeneity in studies reflects underlying differences in clinical diversity of the herds and fats used, differences in study design and analytical methods, and statistical variation around responses. Identifying the presence and sources of the heterogeneity improves understanding of the responses to fats.
We used an $\alpha$ level of 0.10 because of the relatively poor power of the $\chi^{2}$ test to detect heterogeneity among small numbers of trials (Egger and Davey Smith, 2003). Heterogeneity of results among the trials was quantified using the $I^{2}$ statistic (Higgins and Thompson, 2002; Higgins et al., 2003). Higgins and Thompson (2002) developed measures of the effect of heterogeneity on a meta-analysis, from mathematical criteria, that are independent of the number of studies and the treatment effect metric. Higgins and Thompson (2002) proposed 3 suitable statistics: $\mathrm{H}$ is the square root of the $\chi^{2}$ heterogeneity statistic divided by its degrees of freedom; $\mathrm{R}$ is 
the ratio of the standard error of the underlying mean from a random effects meta-analysis to the standard error of a fixed effect meta-analytic estimate; and $I^{2}$ is a transformation of $\mathrm{H}$ that describes the proportion of total variation in study estimates that is due to heterogeneity. Negative values of $I^{2}$ were assigned a value of zero; consequently, the value $I^{2}$ lies between 0 and $100 \%$. An $I^{2}$ value $>50 \%$ may be considered indicative of substantial heterogeneity.

Meta-Regression. Meta-regression analyses were used to explore the source of heterogeneity of response, using the individual SMD for each trial as the outcome and the associated standard error as the measure of variance. It is appropriate to use meta-regression to explore sources of heterogeneity even if an initial overall test for heterogeneity is nonsignificant (Higgins and Thompson, 2002). This also allows us to quantify the magnitude as a function of the a priori defined covariate changing and exploring reasons for heterogeneity (i.e., possible/probable study-level predictors). Metaregression is also a technique that can formally test whether evidence exists of different effects in different subgroups of trials (Knapp and Hartung, 2003). The random effects meta-regression with one covariate and additional between trial variance is given by the following equations (Thompson and Sharp, 1999). Metaregression is the regression of $y_{i}$ on $x_{i}$ with weight $W_{i}=$ $1 / \mathrm{v}_{\mathrm{i}}$ (Thompson and Sharp, 1999):

$$
\begin{gathered}
y_{i} \sim \mathrm{N}\left(\alpha+\beta x_{i}, v_{i}\right), \\
y_{i} \sim \mathrm{N}\left(\alpha+\beta x_{i}, \varphi v_{i}\right), \\
y_{i} \sim \mathrm{N}\left(\alpha+\beta x_{i}, v_{i}+\tau^{2}\right),
\end{gathered}
$$

where $y_{i}$ is the observed parameter of interest, $x_{i}$ is the value of trial-specific covariate, $v_{i}$ is the variance of effect size within trial $i, \beta$ (slope) represents the change in the parameter of interest (milk production) per unit of change in the covariate $x_{i}$, and $\alpha$ (intercept; i.e., $\alpha=$ $\left.0 ; y_{0} \mid x_{0}\right)$, is the parameter of interest if the covariate is equal to zero (Thompson and Sharp, 1999; equation [1]). To incorporate residual heterogeneity into the model to allow a multiplicative factor, greater than 1 , to apply to each of the variance $v_{i}$, the model then becomes equation [2], where $\varphi$ is an overdispersion parameter. Another method (equation [3]) of incorporating residual heterogeneity is to include an additive between-study variance component, $\tau^{2}$ (Thompson and Sharp, 1999). In order to include more than one covariate in the model, we used the methods of Knapp and Hartung (2003). This method was extended to the case of more than one covariate in the meta-regression, and the use of the smoothed within-trial variance estimates to improve hypothesis testing with regard to the significance levels. Knapp and Hartung (2003) have demonstrated the superior properties of alternative estimates of variance from random effects meta-regression (equation [4]). They multiplied the usual standard errors $S E(\hat{\beta} j)$ by $\max \{1, \sqrt{q}\}$, where (Knapp and Hartung, 2003)

$$
q=\frac{1}{k-m-1} \sum \frac{\left(y_{i}-X_{i} \hat{\beta}\right)^{2}}{\tau}
$$

and $v_{i}^{*}=\left(v_{i}+\tau^{2}\right)$ is the marginal variance of $y_{i}$. The modified Wald statistics are compared with a t-distribution with $k-m-1$ degrees of freedom, where $k$ is the number of trials and $m$ is the number of study-level covariates.

The permutation test approach for assessing the statistical significance of meta-regression methods suggested by Higgins and Thompson (2004), and programmed by Harbord and Higgins (2008) and Harbord and Steichen (2004), was used in this paper to reduce the risk of type I error. Higgins and Thompson (2004) used Monte Carlo simulation to investigate the type I error rate of the commonly used, frequentist metaregression methods in various situations and to address limitations in the previously available methods. They proposed a permutation test approach for assessing the statistical significance of an observed meta-regression finding. The data are simulated under the null hypothesis of no association between effect estimates and any covariate, yet with an unexplained component of heterogeneity according to the standard random effects meta-analysis model. Without loss of generality, the average effect was assigned to zero (Higgins and Thompson, 2004):

$$
\theta_{i} \sim \mathrm{N}\left(0, \tau^{2}\right)
$$

where $y_{\mathrm{i}} \sim \mathrm{N}\left(\theta_{i}, v_{i}\right)$ for $i=1, \ldots, k$.

Covariates are simulated from a multivariate (standard) normal distribution so that correlation is imposed between pairs of covariates. This process provides an assessment less likely to produce type I statistical error (Higgins and Thompson, 2004).

Meta-regression analysis was conducted by first screening individual variables using a $P$-value of $\leq 0.20$. All variables with $P$-value of $\leq 0.20$ were entered into a forward stepwise weighted meta-regression until all remaining variables were significant at $P<0.05$. 
Factors that were examined included start date of supplementation (before or after calving), duration of treatment before calving, duration of treatment after calving, types of fat, number of milkings per day (2 vs. 3 ), parity of cows (primiparous vs. multiparous herds vs. mixed herds with multiparous and primiparous), amount of fat products, and differences in dietary nutrients estimated from the CPM analysis between the treatment and control groups. Data were screened for plausible quadratic relationships between differences in concentrations of nutrients in the diet between the treatment and control group and the outcomes.

Publication Bias. The presence of publication bias is commonly investigated using funnel plots. A funnel plot is a simple scatter plot of the intervention effect estimates from individual studies plotted against measures of each study's size or precision. The plot is commonly presented with the effect estimates on the horizontal scale, and a measure of variance on the vertical axis. The name "funnel plot" arises because precision of the estimated intervention effect increases as the size of the study increases. Effect estimates from small studies will therefore scatter more widely at the bottom of the graph and the spread narrows for larger studies. In the absence of bias, the plot should approximately resemble a symmetrical (inverted) funnel. If bias exists (e.g., because smaller studies without statistically significant effects remain unpublished), this will lead to an asymmetrical appearance of the funnel plot, and a gap will be evident in a bottom corner of the graph. In this situation, the effect calculated in a meta-analysis will tend to overestimate the intervention effect. The more pronounced the asymmetry, the more likely it is that the bias will be substantial.

Contour-Enhanced Funnel Plots. Contourenhanced funnel plots have been used by Peters et al. (2008) to include contour lines corresponding to statistical significance $(P=0.01,0.05,0.1)$. This approach allowed the statistical significance of study estimates and areas in which studies are perceived to be missing to be considered. The contour-enhanced funnel plots may help to differentiate asymmetry caused by publication bias from that due to other factors. For example, if studies appear to be missing in areas of statistical nonsignificance, then this adds credence to the possibility that the asymmetry is caused by publication bias. Conversely, if the supposed missing studies are in areas of higher statistical significance, this suggests that the observed asymmetry may be more likely to be due to factors other than publication bias; for example, variable study quality or a failure to publish findings that were not statistically significant.

\section{RESULTS AND DISCUSSION}

\section{Review of the Data}

We critically reviewed all the data obtained and summarized findings on each study in Table 1 . Some studies contained a summary of a single trial, whereas other studies reported multiple comparisons such as different doses of fat supplement or parities of cattle, or used factorial designs to examine different aspects of responses to fat treatments. A wide range of fat and oil sources was used in these studies, and the presence or absence of fats in the control diets and fats used in control diets was very variable. Fat treatments were grouped according to several categories that were identified a priori as being suitable to evaluate. These included the tallow group $(\mathrm{n}=15$; tallow, white grease, and yellow grease); calcium salts of palm fatty acids $(n=25$; these consisted entirely of studies using Megalac, Church and Dwight Co. Inc., Princeton, NJ); oilseeds ( $\mathrm{n}=30$; whole cottonseed, whole sunflower, whole soybeans, and oils derived from these); prilled fatty acids $(\mathrm{n}=4$; hydrolyzed fatty acids); and other calcium salts ( $\mathrm{n}=$ 10; flaxseed, fish oil, linseed). We found relatively few randomized controlled studies with prilled FA; however, these were included in the evaluation. A previous metaanalysis demonstrated that fats fed in one period of a Latin square study could be remobilized in a subsequent period (Duffield et al., 2008). Many studies conducted using Latin square designs were of short duration and this may influence outcomes (Block and Evans, 2010b). Consequently, Latin square studies were not considered for this study. A similar number of studies was identified in previous quantitative assessments conducted by Allen (2000) and Onetti and Grummer (2004); however, these studies used different data, as Latin square studies were used by Allen (2000) and some were included by Onetti and Grummer (2004), who also examined effects of fat supplements on acetate:propionate ratios and fiber digestion. Our database excluded 46 studies used by Allen (2000), contained 15 mutually accepted studies, and included 32 not used by Allen (2000). We excluded 27 studies used by Onetti and Grummer (2004), mutually included 8 studies, and included 35 not used by Onetti and Grummer (2004). This study includes studies published after 2004, but only randomized controlled trials, and investigates sources of the heterogeneity or variation in responses to treatments.

The need to control for covariates reflects the marked variability in study design among studies. In particular, with a relatively large inclusion of a nutritional intervention such as fats, there will be effects on other dietary components. The unavoidable change in dietary 
Table 3. Standardized mean difference (SMD) and estimated mean differences with $95 \%$ CI of milk yield, DMI, and milk compositions in lactating dairy cows supplemented with different fat products

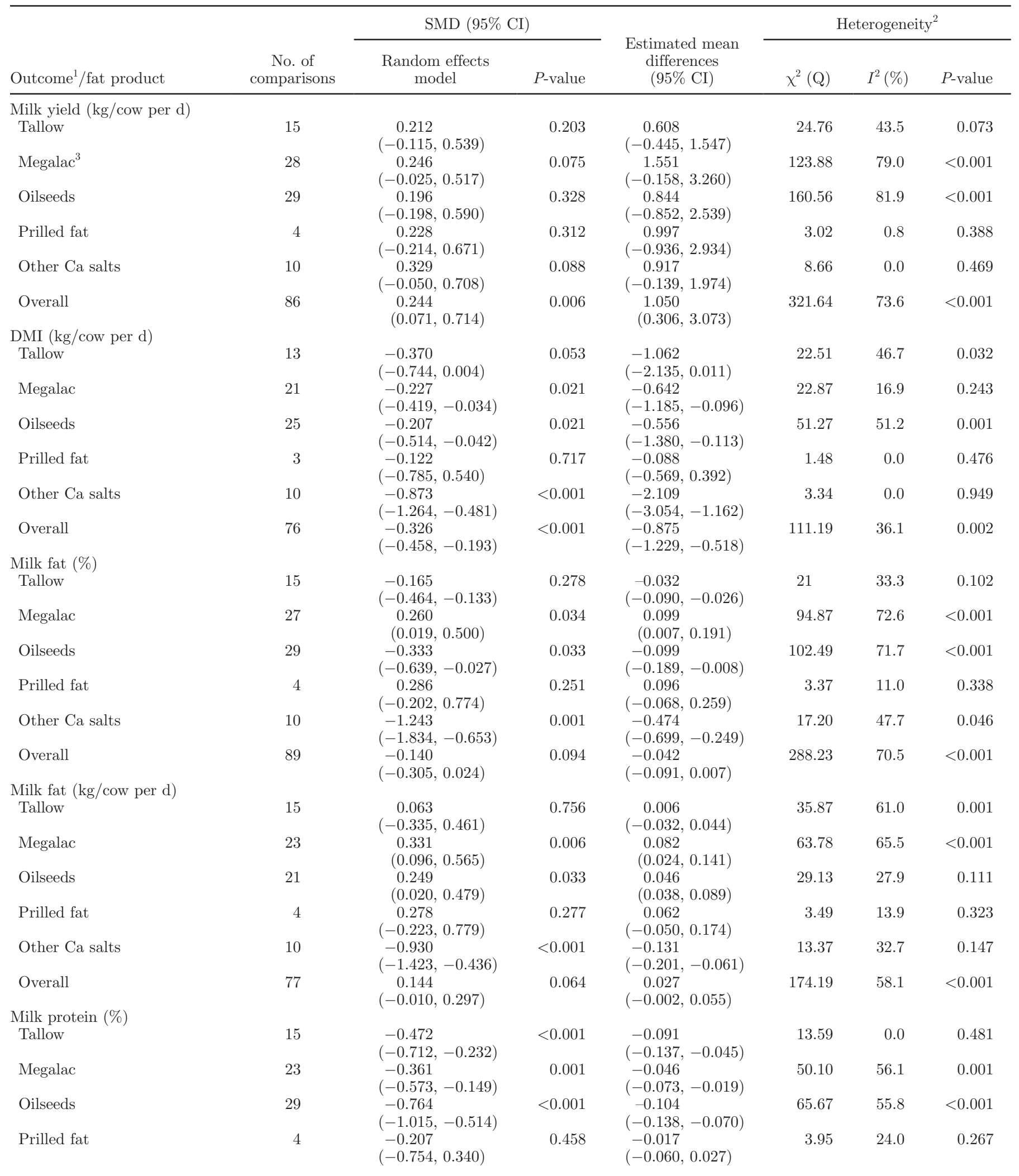


Table 3 (Continued). Standardized mean difference (SMD) and estimated mean differences with 95\% CI of milk yield, DMI, and milk compositions in lactating dairy cows supplemented with different fat products

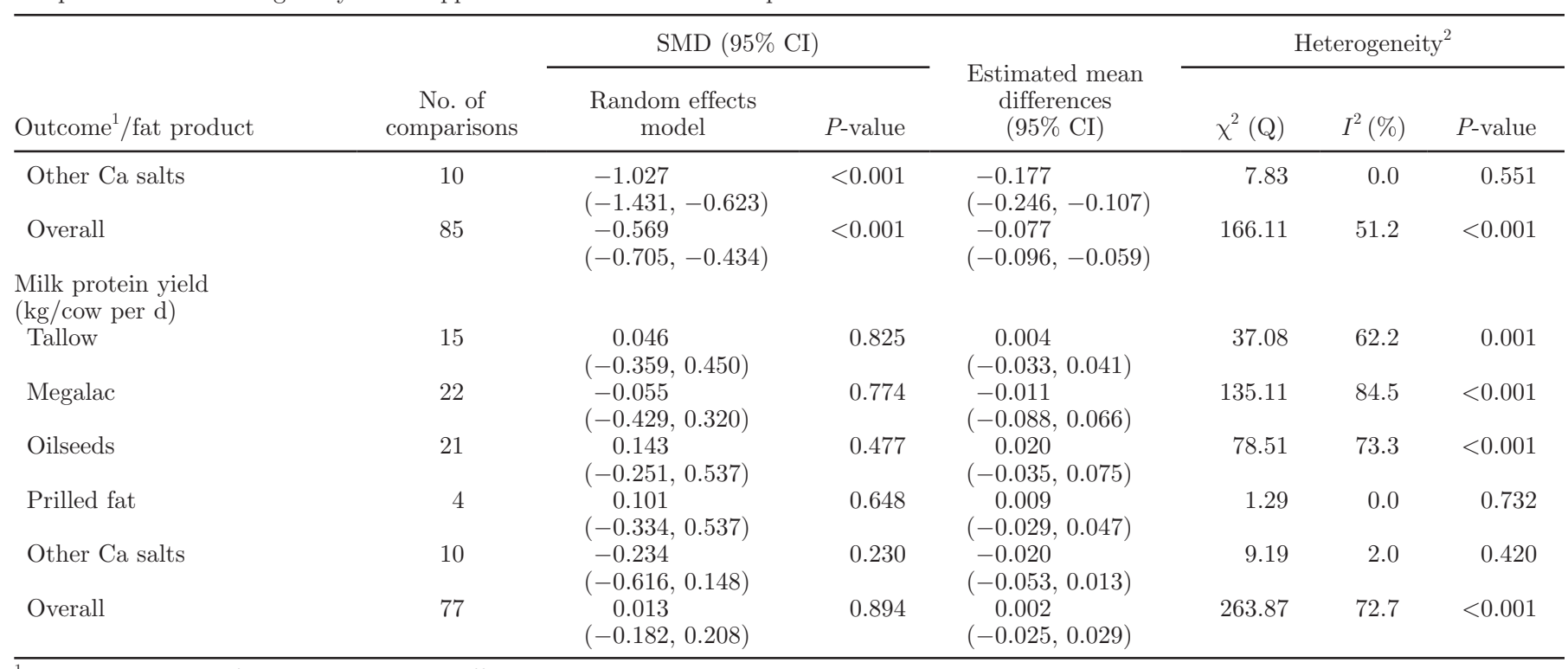

${ }^{1}$ Units are provided for estimated mean differences.

${ }^{2} \chi^{2}$ and $I^{2}$ provided to show the degree of heterogeneity among studies included in the meta-analysis.

${ }^{3}$ Church and Dwight Co. Inc. (Princeton, NJ).

inclusions raises questions concerning interpretation of individual studies because of the confounding effects of change in carbohydrate, protein, mineral, and micronutrient content of the diet and possibly in metabolism as a result of the fat inclusion. Despite the potential for confounding to result as a function of treatment intervention, we are not aware of previous detailed considerations of the role of this form of confounding in nutritional studies. The potential for this problem to influence the outcomes of reproductive studies has been addressed in the literature (Ferguson and Chalupa, 1989; Lean et al., 2012).

Univariate associations between variables examined and the SMD for milk production are provided in Table 2. In previous meta-analytic publications (Rabiee et al., 2010; Lean and Rabiee, 2011), methods described by Knapp and Hartung (2003) and Higgins and Thompson (2002) for the conduct of multivariate meta-regression have been used. Higgins and Thompson (2004) used Monte Carlo simulation methods to investigate the type I error rate resulting from the use of frequentist metaregression methods and to address limitations in these methods. Higgins and Thompson (2004) found that standard meta-regression methods could have substantially inflated false-positive rates when heterogeneity is present, such as in the present study. False positives (type I error) especially result when there are few studies and many potential covariates. Investigations of differences among studies, within studies, and the results are observational associations and are subject to biases, including aggregation bias, and confounding resulting from correlation among covariates (Thompson and Higgins, 2002). False-positive results are more likely in meta-regression than in conventional regression because heterogeneity can be present. It is not clear how many covariates can reliably be investigated, and how this might depend on the number of studies, the extent of the heterogeneity, and the relative weights awarded to the different studies (Higgins and Thompson, 2004). Therefore, although comparisons and trial numbers for this study were quite large, the large number of potential covariates may have increased the risk of type I error. We tried to control this risk by the process of careful univariate screening and the method recommended by Higgins and Thompson (2004) for meta-regression. Nonetheless, alternate and valid multivariate models could have been developed, and univariate associations presented in the Appendix should be evaluated closely for biological plausibility.

\section{Production Outcomes and Discussion}

Univariate statistics on the diets and differences in diets among the treatment and control groups are provided in Table 2. Meta-analysis of different types of fat products is provided in Table 3 and Figure 1.

The milk production responses to fats overall were significant and the SMD production increase was 1.05 
$\mathrm{kg} /$ cow per day, but results were very heterogeneous $\left(I^{2}=73.6 \%\right)$. The average estimated increase in ether extract fed to the treatment group was $2.59 \%$ of the diet, the average feed intake of all groups was $22.0 \mathrm{~kg} /$ cow per day, and the estimated mean difference in DMI between the treatment and control groups was -0.88 $\mathrm{kg} /$ cow per day (Table 3). The highest SMD estimate of milk production was for other Ca salts, which markedly, but not significantly, increased milk production (Table 3). Similarly, Megalac (1.55 kg/cow per day) and prilled fat $(1.00 \mathrm{~kg} /$ cow per day) substantially, but not significantly, increased milk production. The SMD, which are $z$-scores, are more robust measures than the weighted mean difference estimates to evaluate the effect of treatment. In all cases, however, the effects on milk production of treatment groups were positive, approached significance in the case of other Ca salts and Megalac, but were also significantly heterogeneous for oilseeds and Megalac (Table 3). The milk production responses, estimated mean differences $(\mathrm{kg} / \mathrm{cow}$ per day) for tallow, Megalac, and prilled fats were consistent, within $0.25 \mathrm{~kg} / \mathrm{cow}$ per day, with the least squares means estimates in a previous quantitative study of responses to fat supplementation (Onetti and Grummer, 2004). The funnel plot, evaluating publication bias (Figure 2), provided little evidence of publication bias, because it seemed to be symmetrical but showed the profound effect and heterogeneity of milk production responses to fats, as indicated by highly significant positive, and negative, responses to treatment.

All the significant meta-regression covariate effects in the final multivariate model explaining sources of variance in the SMD for milk production (Table 4) are consistent with biological effects previously reported. Milk yield increased with increased differences in DMI between the treatment and control group, and decreased with predicted ME balance between groups, probably reflecting the partitioning of nutrients toward body tissue. Milk production also decreased with increased difference in soluble protein percentage of the diet between treatment and control diets. Univariate meta-regression results (Appendix) showed a strong increase in milk production response to fat supplementation in 3-times-a-day milking comparisons, but this did not remain significant in final meta-regression models.

Dry matter intake was decreased by all fat interventions, and the estimated mean difference for this decrease was $0.88 \mathrm{~kg} / \mathrm{cow}$ per day (Table 3). Decreases in DMI were significant for Megalac, oilseeds, and other Ca salts, approached significance for tallow $(P<0.06)$, and were not significantly heterogeneous for Megalac, prilled fat, and other Ca salts. The reduction of DMI for other Ca salts had an SMD 2 to 3 times greater than for other fat sources, and the estimated mean difference was a substantial $2.11 \mathrm{~kg} / \mathrm{cow}$ per day that was homogeneous despite differences in composition within the other Ca salts group. A reduction in DMI is consistent with the conclusions of other researchers; however, the observation that other Ca salts may have a large effect on feed intake appears to be novel. A quantitative review of literature on the effects of diet on short-term feed intake (Allen, 2000) suggested that calcium salts of palm fatty acids reduced DMI more than other sources. In this study, other Ca salts was the only group to have a significantly lower DMI, and the SMD for Megalac was consistent with that of other groups. Allen (2000) also suggested that hypophagic effects of fat increase with the proportion of unsaturated fatty acids, and the findings for other Ca salts support this contention to some degree, but the lesser effect of oilseeds suggests that these effects may be more substantial for unsaturated fats at the duodenal level. Although univariate meta-regression showed that DMI significantly decreased with a quadratic increase in the difference in EE between the control and treatment diet, no significant effect of this or level of EE in the diet on DMI was found once other responses were controlled for in multivariate analyses. The final metaregression model for DMI found that a longer period of feeding fat resulted in a higher DMI. Weiss and PinosRodríguez (2009) found significant differences in the effect of prilled fat on DMI; in early lactation, additional fat increased DMI, but late in lactation, the same fat decreased DMI. Differences between DMI responses to Megalac treatment in our study and that of Allen (2000) may reflect differences in study inclusion criteria, particularly the inclusion of shorter term Latin-square studies, and in methods of statistical analysis. Greater differences in the amount of soluble protein percentage of the diet between the control and treatment diet also significantly decreased DMI, a finding consistent with that of Allen (2000), who found in regression analysis that the DMI increased with increased CP content of the control diets. We found little evidence of publication bias in the DMI responses, and many of the studies showed a very large effect in reducing DMI (Figure 2). Given the tendency of the Megalac and other Ca salts to increase milk production and significantly reduce DMI, it is likely that these improve the efficiency of milk production.

The milk fat percentage response varied in point direction with different fats, with tallow, oilseeds, and other Ca salts reducing milk fat, and Megalac and prilled fat increasing the fat percentage. Results for milk fat percentage were significantly heterogeneous for fat source. The estimated SMD for Megalac and prilled fat were very similar and significantly heterogeneous for Megalac (Table 4). The other Ca salts had a very 

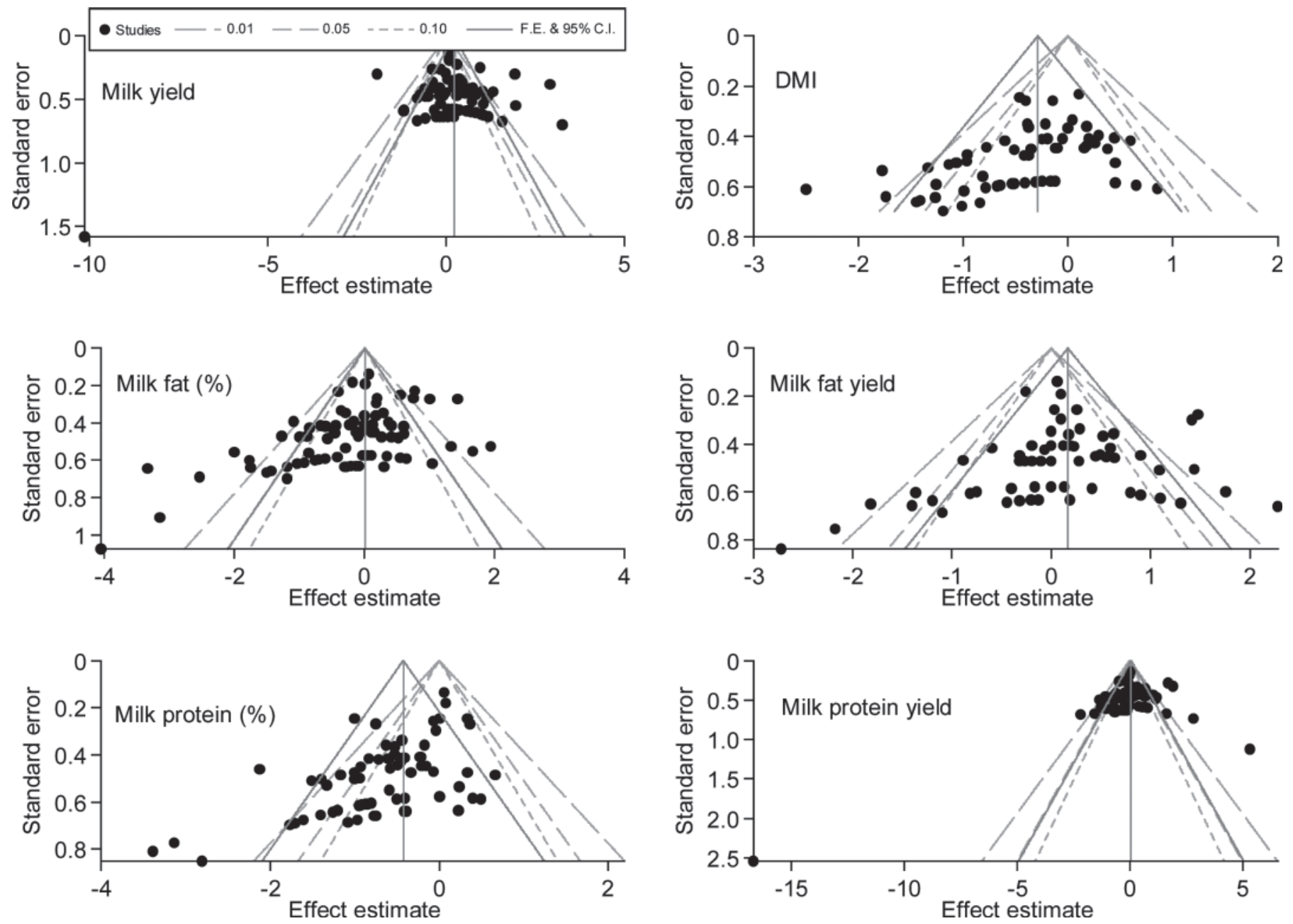

Figure 2. Contour-enhanced funnel plots of production data and DMI for cows supplemented with fat. Levels of significance for studies (•) within the gray broken lines are 0.01, 0.05, and 0.10; FE = fixed effect. Effect estimates from small trials and comparisons will scatter more widely at the bottom of the graph and the spread narrows for larger trials and comparisons. In the absence of bias, the plot should approximately resemble a symmetrical (inverted) funnel. Contour lines corresponding to statistical significance $(P=0.01,0.05,0.1)$ to allow the statistical significance of trials and comparisons estimates and areas in which trials and comparisons are perceived to be missing to be considered. If trials and comparisons appear to be missing in areas of statistical nonsignificance, then this adds credence to the possibility that the asymmetry is caused by publication bias. Conversely, if the supposed missing trials and comparisons are in areas of higher statistical significance, this suggests that the observed asymmetry is more likely to be due to factors other than publication bias.

large effect in reducing milk fat percentage. The funnel plot for milk fat percentage showed little evidence of publication bias for this result. This plot highlighted, however, the substantial and differing biological effects of dietary fat intakes on milk fat percentage. Some studies showed large, significant, positive effects on milk fat percentage and others had markedly, and very significantly, lowered milk fat percentage with treatment (Figure 2). The sources of fats used in the other Ca salts included fish oils, linseed, and flax oils, and the estimated mean difference of $-0.48 \%$ for the effects of other Ca salts on milk fat percentage was large (Table $3)$.
Moate et al. (2008) conducted a quantitative analysis of dietary factors influencing milk fatty acid production and observed that dietary inclusion of fish oils decreased de novo synthesis of milk fatty acids, and had a quadratic effect on production $(\mathrm{g} / \mathrm{d})$ of $\mathrm{C} 16: 0$ and cis-9 C16:1 milk fatty acids. It is also possible that milk fat depression may reflect increased production of trans-10,cis-12 C18:2 conjugated linoleic acid. Moate et al. (2008) found that the production of this fatty acid in milk increased with the estimated increased absorption of C18:2 fatty acids from the intestine. The current study and that of Moate et al. (2008) provide evidence with high external validity that supports the elegant 
Table 4. Multivariate meta-regression using Knapp and Hartung (2003) modification and simulation procedures (Higgins and Thompson, 2004)

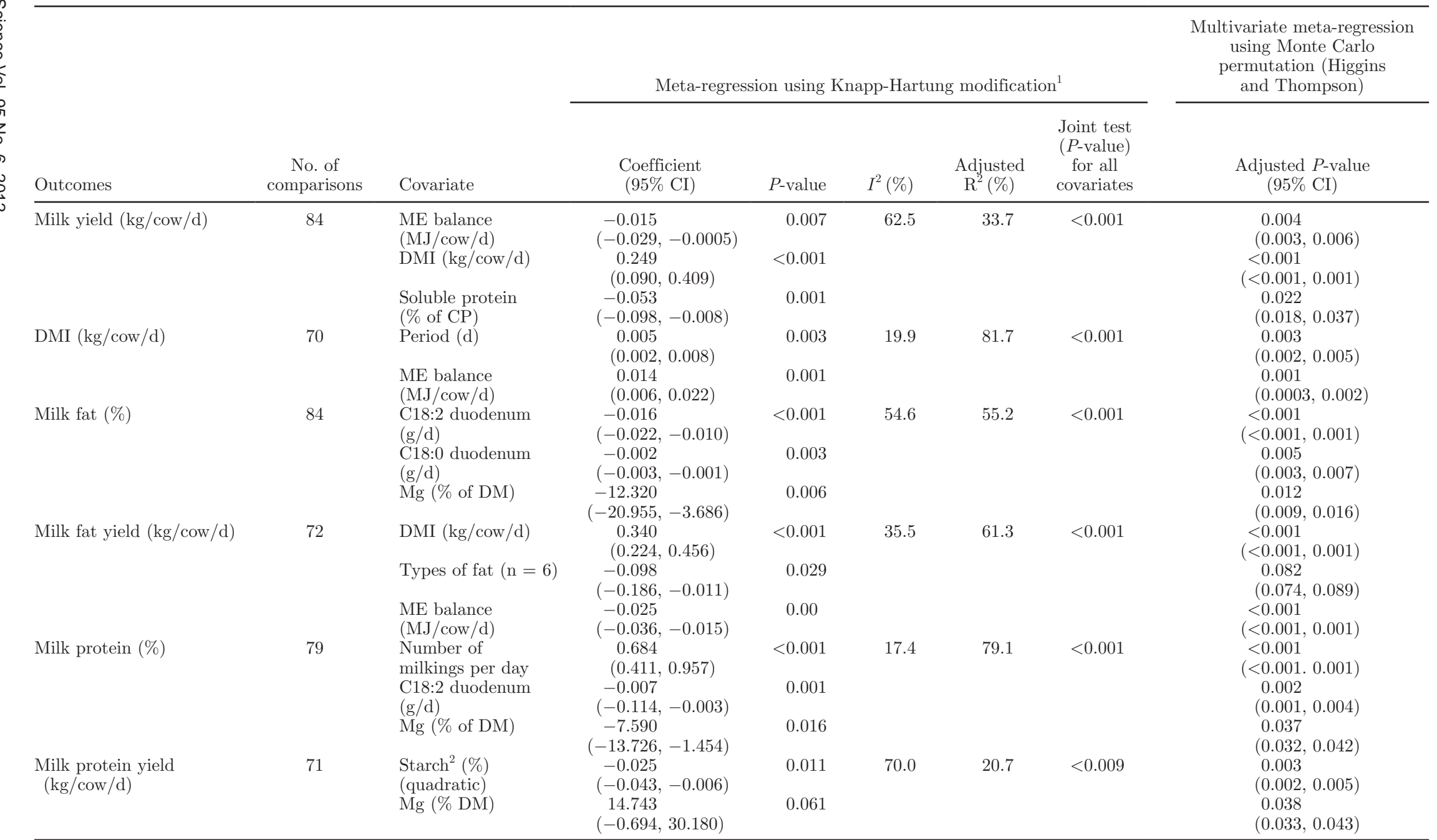

${ }^{1} I^{2}=$ percentage of residual variation due to heterogeneity; adjusted $\mathrm{R}^{2}=$ proportion of between-study variance explained; joint test for all covariates included using Knapp-Hartung modification methods. 
physiological studies of Baumgard et al. (2000) in which abomasal infusion of trans-10,cis-12 C18:2 conjugated linoleic acid decreased milk fat concentrations. Further support for this hypothesis comes from the meta-regression results (Table 4), in which estimated differences between the treatment and control groups in duodenal concentrations of C18:2 fatty acids reduced the milk fat percentage SMD. We found negative effects on milk fat percentage from the increased difference in $\mathrm{C} 18: 0$ and $\mathrm{Mg}$ percentage of the diet between the treatment and control groups. The coefficient for the effect of the difference in estimated C18:0 uptake at the duodenum between treatment and control groups was relatively small, and the negative effect may reflect the intake of unsaturated precursors of C18:0 and the effect of these on milk fatty acid synthesis. Although C18:0 is desaturated to cis-9 C18:1 in the mammary gland (Soyeurt et al., 2008), there is no evidence that cis-9 C18:1 reduces milk fat percentage per se (Lock et al., 2007). However, high concentrations of cis-9 C18:1 in milk fatty acids are associated with milk fat depression (Bauman and Griinari, 2003), and an infusion of $92.1 \mathrm{~g} / \mathrm{d}$ of a mixture of C18:1 isomers (Shingfield et al., 2009) depressed milk secretion by $19.5 \%$, suggesting that the role of $\mathrm{C} 18: 0$ and $\mathrm{C} 18: 1$ isomers in milk fat depression is worthy of further examination. Magnesium is a critical part of milk fatty acid synthetase; consequently, the carboxylation of acetyl CoA to malonyl CoA is magnesium dependent (Storry, 1970), and addition of magnesium oxide to the diet has been reported to increase milk fat percentage in some (Thomas and Emery, 1969) but not all studies (Kalscheur et al., 1997). The range of difference between groups in $\mathrm{Mg}$ percentage was small, approximately $0.1 \%$; however, this finding supports that of Moate et al. (2008), who found a decrease in fat percentage with high intakes of magnesium oxide. The surprisingly large coefficient is consistent with a large negative effect on stearic acid production identified in the Moate et al. (2008) study.

Milk fat yield tended to increase with fat treatments $(P<0.07)$; however, the other Ca salts significantly and substantially reduced milk fat yield (Table 3). Of the remaining fat sources, the Megalac and oilseeds significantly increased fat yield. Meta-regression results showed that fat yield increased with increased DMI difference between the treatment and control groups and was lower with an increased estimated ME balance between the treatment and control groups (Table 4). The lower fat yield with estimated ME balance difference probably reflects increased partitioning of fat to body tissue reserves. The effect of the other Ca salts remained significant in the meta-regression model; however, the coefficient was not very large, indicating that the large effects that these had on fat yield may have been mediated, in part, through partitioning of energy to body tissue and through DMI. We are not aware of any studies showing a significant positive effect of calcium protected unsaturated fats (such as those in the other Ca salts) on body tissue partitioning, and this observation should be tested in further studies. Pantoja et al. (1995) found an increase in BCS with increased saturation of fat. The funnel plot (Figure 2) shows no evidence of publication bias. The very substantial differences in effect size and direction among studies presented in the funnel plot again indicates the profound differences in biological effects of fat treatments on milk fat production in the comparisons assessed.

Feeding fats decreased milk protein percentage; however, the results were significantly heterogeneous (Table 3 ). Of the individual groups, prilled fat had the least effect on milk protein percentage; the SMD was small and not significant (Table 4). The effects of Megalac were significant and the estimated mean difference $(0.05 \%$ decrease $)$ was heterogeneous. Tallow consistently lowered milk protein percentage $\left(I^{2}=0.0 \%\right)$ by $0.09 \%$. Oilseeds feeding decreased milk protein percentage with a large SMD and estimated mean difference, but results were heterogeneous, whereas the largest estimated mean difference decrease $(0.18 \%)$ was for the other Ca salts. The results for this effect were homogeneous. Meta-regression results showed that number of milkings increased the milk protein percentage, whereas the estimated difference between the treatment and control groups in duodenal concentrations of 18:2 fatty acids reduced the milk protein percentage SMD. The coefficient for the latter effect was small, whereas the coefficient for the difference in magnesium concentration between treatment and control diets was large and negative. The range of difference in magnesium between treatment and control groups was small, however, and care should be taken in extrapolating this response. $\mathrm{Wu}$ and Huber (1994) similarly identified negative effects of fat feeding on milk protein percentage and speculated on possible causes. Wu and Huber (1994) hypothesized that decreased glucose availability, development of insulin resistance, increased efficiency of milk production, or reduced plasma somatotropin may be involved in the decreased percentage. Cant et al. (1993) found evidence of lesser amino acid supply to the mammary gland when fats were fed. Our meta-regression analysis identified 3 factors present in the study database, but could not specifically test hypotheses raised by $\mathrm{Wu}$ and Huber (1994) or Cant et al. (1993). The 3 factors identified should be tested in randomized controlled trials to further examine the nature of the responses.

None of the fat treatments significantly influenced milk protein production, although the other $\mathrm{Ca}$ salts had a substantial negative point direction (Table 3). 
The milk protein yield results for fat feeding overall for tallow, oilseeds, and Megalac were all heterogeneous, and the estimated mean differences were all small effects with the exception of other Ca salts, which had a more substantial negative result. The meta-regression model developed to examine responses in milk protein yield identified a quadratic effect of difference in starch content between the treatment and control diets, a linear increase in milk protein yield response to sugar intake difference, a positive linear response to difference in magnesium, and a linear negative response to the difference in percentage of methionine requirement between the treatment and control diets (Table 4). The starch and sugar responses indicate a benefit in yield of protein with increased fermentability of the diet based on increased total starch or sugar content. The strong positive response to magnesium may reflect a more stable rumen with increased control of acidosis risk; however, the small range in which this finding was made suggests the need for cautious interpretation.

\section{CONCLUSIONS}

Inclusions of fat in the diets had marked effects on milk, milk fat, production, DMI, and content of fat and protein in milk. The range of responses to the different fats fed exceeded or approached 5 standard deviations from the mean and had different point directions for all variables studied, indicating the varied and marked biological effect of these treatments. Responses to fat feeding were highly heterogeneous for all variables studied; however, milk production and milk fat percentage and yield increased, DMI and milk protein percentage decreased, and milk protein yield was not significantly affected by fat feeding. The heterogeneity in response was present within many of the responses to the individual fat groups studied. Meta-regression using variables that described differences in study designs, differences in components or outcomes of diets assessed using CPM-Dairy demonstrated that the effects of fats on outcomes were influenced by study design and diet. The lower DMI with fat feeding and higher milk and milk fat production showed that fats improve the efficiency of milk production; however, more studies are required to thoroughly characterize the sources of variation in responses to fats.

\section{ACKNOWLEDGMENTS}

This study was funded and supported by Church and Dwight Co. Inc. (Princeton, NJ).

\section{REFERENCES}

Allen, M. S. 2000. Effects of diet on short-term regulation of feed intake by lactating dairy cattle. J. Dairy Sci. 83:1598-1624.

Allred, S. L., T. R. Dhiman, C. P. Brennand, R. C. Khanal, D. J. McMahon, and N. D. Luchini. 2006. Milk and cheese from cows fed calcium salts of palm and fish oil alone or in combination with soybean products. J. Dairy Sci. 89:234-248.

Bauman, D. E., and J. M. Griinari. 2003. Nutritional regulation of milk fat synthesis. Annu. Rev. Nutr. 23:203-227.

Baumgard, L. H., B. A. Corl, D. A. Dwyer, A. Saebo, and D. E. Bauman. 2000. Identification of the conjugated linoleic acid isomer that inhibits milk fat synthesis. Am. J. Physiol. Regul. Integr. Comp. Physiol. 278:R179-R184.

Baumgard, L. H., E. Matitashvili, B. A. Corl, D. A. Dwyer, and D. E. Bauman. 2002. Trans-10, cis-12 conjugated linoleic acid decreases lipogenic rates and expression of genes involved in milk lipid synthesis in dairy cows. J. Dairy Sci. 85:2155-2163.

Bertrand, J. A., and L. W. Grimes. 1997. Influence of tallow and Aspergillus oryzae fermentation extract in dairy cattle rations. J. Dairy Sci. 80:1179-1184.

Block, E., and E. Evans. 2010a. A model to compare effects of supplemental fat sources on performance and dry matter intake in dairy cows: Effects of fat inclusion level. J. Dairy Sci. 93(E-Suppl. 1):440. (Abstr.)

Block, E., and E. Evans. 2010b. A model to compare the effects of fat sources upon performance and dry matter intake: Effects of trial duration. J. Dairy Sci. 93(E-Suppl. 1):440. (Abstr.)

Calder, P. C. 2006. Polyunsaturated fatty acids and inflammation. Prostaglandins Leukot. Essent. Fatty Acids 75:197-202.

Cant, J. P., E. J. DePeters, and R. L. Baldwin. 1993. Mammary amino acid utilization in dairy cows fed fat and its relationship to milk protein depression. J. Dairy Sci. 76:762-774.

Casper, D. P., D. J. Schingoethe, and W. A. Eisenbeisz. 1990. Response of early lactation cows to diets that vary in ruminal degradability of carbohydrates and amount of fat. J. Dairy Sci. 73:425-444.

Chan, S. C., J. T. Huber, C. B. Theurer, Z. Wu, K. H. Chen, and J. N. Simas. 1997. Effects of supplemental fat and protein source on ruminal fermentation and nutrient flow to the duodenum in dairy cows. J. Dairy Sci. 80:152-159.

Chouinard, P. Y., V. Girard, and G. J. Brisson. 1997. Lactational response of cows to different concentrations of calcium salts of canola oil fatty acids with or without bicarbonates. J. Dairy Sci. 80:1185-1193.

Chouinard, P. Y., V. Girard, and G. J. Brisson. 1998. Fatty acid profile and physical properties of milk fat from cows fed calcium salts of fatty acids with varying unsaturation. J. Dairy Sci. 81:471-481.

Cohen, J. 1988. Statistical Power Analysis for the Behavioral Sciences. 2nd ed. Academic Press, New York, NY.

DerSimonian, R., and N. Laird. 1986. Meta-analysis in clinical trials. Control. Clin. Trials 7:177-188.

Dhiman, T. R., E. D. Helmink, D. J. McMahon, R. L. Fife, and M. W. Pariza. 1999. Conjugated linoleic acid content of milk and cheese from cows fed extruded oilseeds. J. Dairy Sci. 82:412-419.

Drackley, J. K., and D. J. Schingoethe. 1986. Extruded blend of soybean meal and sunflower seeds for dairy cattle in early lactation. J. Dairy Sci. 69:371-384.

Driver, L. S., R. R. Grummer, and L. H. Schultz. 1990. Effects of feeding heat-treated soybeans and niacin to high producing cows in early lactation. J. Dairy Sci. 73:463-469.

Duffield, T. F., A. R. Rabiee, and I. J. Lean. 2008. A meta-analysis of the impact of monensin in lactating dairy cattle. Part 1. Metabolic effects. J. Dairy Sci. 91:1334-1346.

Duske, K., H. M. Hammon, A. K. Langhof, O. Bellmann, B. Losand, K. Nürnberg, G. Nürnberg, H. Sauerwein, H. M. Seyfert, and C. C. Metges. 2009. Metabolism and lactation performance in dairy cows fed a diet containing rumen-protected fat during the last twelve weeks of gestation. J. Dairy Sci. 92:1670-1684.

Egger, M., and G. Davey Smith. 2003. Principles of and procedures for systematic reviews. Pages 23-42 in Systematic Reviews in Health 
Care Meta-Analysis in Context. M. Egger, G. Davey Smith, and D. G. Altman, ed. British Medical Journal Books, London, UK.

Erickson, P. S., M. R. Murphy, and J. H. Clark. 1992. Supplementation of dairy cow diets with calcium salts of long-chain fatty acids and nicotinic acid in early lactation. J. Dairy Sci. 75:1078-1089.

Faldet, M. A., and L. D. Satter. 1991. Feeding heat-treated full fat soybeans to cows in early lactation. J. Dairy Sci. 74:3047-3054.

Ferguson, J. D., and W. Chalupa. 1989. Impact of protein nutrition on reproduction in dairy cows. J. Dairy Sci. 72:746-766.

Finn, A. M., A. K. Clark, J. K. Drackley, D. J. Schingoethe, and T. Sahlu. 1985. Whole rolled sunflower seeds with or without additional limestone in lactating dairy cattle rations. J. Dairy Sci. 68:903-913.

Garcia-Bojalil, C. M., C. R. Staples, C. A. Risco, J. D. Savio, and W. W. Thatcher. 1998. Protein degradability and calcium salts of long-chain fatty acids in the diets of lactating dairy cows: Productive responses. J. Dairy Sci. 81:1374-1384.

Griinari, J. M., D. A. Dwyer, M. A. McGuire, D. E. Bauman, D. L. Palmquist, and K. V. V. Nurmela. 1998. Trans-octadecenoic acids and milk fat depression in lactating dairy cows. J. Dairy Sci. 81:1251-1261.

Grummer, R. R. 1988. Influence of prilled fat and calcium salt of palm oil fatty acids on ruminal fermentation and nutrient digestibility. J. Dairy Sci. 71:117-123.

Harbord, R. M., and J. P. T. Higgins. 2008. Meta-regression in Stata. Stata J. 8:493-519.

Harbord, R. M., and T. J. Steichen. 2004. METAREG: Stata module to perform meta-analysis regression. Statistical Software Components S4446201. Revised Jan. 5, 2009. Boston College Department of Economics, Boston, MA.

Harrison, J. H., R. L. Kincaid, J. P. McNamara, S. Waltner, K. A Loney, R. E. Riley, and J. D. Cronrath. 1995. Effect of whole cottonseeds and calcium salts of long-chain fatty acids on performance of lactating dairy cows. J. Dairy Sci. 78:181-193.

Higgins, J. P. T., and S. G. Thompson. 2002. Quantifying heterogeneity in a meta-analysis. Stat. Med. 21:1539-1558.

Higgins, J. P. T., and S. G. Thompson. 2004. Controlling the risk of spurious findings from meta-regression. Stat. Med. 23:1663-1682.

Higgins, J. P. T., S. G. Thompson, J. J. Deeks, and D. G. Altman. 2003. Measuring inconsistency in meta-analysis. BMJ 327:557560.

Hoffman, P. C., R. R. Grummer, R. D. Shaver, G. A. Broderick, and T. R. Drendel. 1991. Feeding supplemental fat and undegraded intake protein to early lactation dairy cows. J. Dairy Sci. 74:3468-3474.

Holter, J. B., H. H. Hayes, W. E. Urban, and A. H. Duthie. 1992 Energy balance and lactation response in holstein cows supplemented with cottonseed with or without calcium soap. J. Dairy Sci. 75:1480-1494.

Jenkins, T. C., J. A. Bertrand, and W. C. Bridges. 1998. Interactions of tallow and hay particle size on yield and composition of milk from lactating Holstein cows. J. Dairy Sci. 81:1396-1402.

Jerred, M. J., D. J. Carroll, D. K. Combs, and R. R. Grummer. 1990. Effects of fat supplementation and immature alfalfa to concentrate ratio on lactation performance of dairy cattle. J. Dairy Sci. $73: 2842-2854$

Kalscheur, K. F., B. B. Teter, L. S. Piperova, and R. A. Erdman. 1997. Effect of dietary forage concentration and buffer addition on duodenal flow of trans-C18:1 fatty acids and milk fat production in dairy cows. J. Dairy Sci. 80:2104-2114.

Khorasani, G. R., and J. J. Kennelly. 1998. Effect of added dietary fat on performance, rumen characteristics, and plasma metabolites of midlactation dairy cows. J. Dairy Sci. 81:2459-2468.

Kim, Y. K., D. J. Schingoethe, D. P. Casper, and F. C. Ludens. 1991. Lactational response of dairy cows to increased dietary crude protein with added fat. J. Dairy Sci. 74:3891-3899.

Kim, Y. K., D. J. Schingoethe, D. P. Casper, and F. C. Ludens. 1993. Supplemental dietary fat from extruded soybeans and calcium soaps of fatty acids for lactating dairy cows. J. Dairy Sci. 76:197204 .
Knapp, G., and J. Hartung. 2003. Improved tests for a random-effects meta-regression with a single covariate. Stat. Med. 22:2693-2710.

Kronfeld, D. S. 1976. The potential importance of the proportions of glucogenic, lipogenic and aminogenic nutrients in regard to the health and productivity of dairy cows. Fortschr. Tierphysiol. Tierernahr. $7: 3-26$.

Lean, I. J., P. Celi, H. Raadsma, J. P. McNamara, and A. R. Rabiee. 2012. Effects of dietary crude protein on fertility: Meta-analysis and meta-regression. Anim. Feed Sci. Technol. 171:31-42.

Lean, I. J., and A. R. Rabiee. 2011. Effect of feeding biotin on milk production and foot health in lactating dairy cows: A meta-analysis. J. Dairy Sci. 94:1465-1476.

Lean, I. J., A. R. Rabiee, T. F. Duffield, and I. R. Dohoo. 2009. Invited review: Use of meta-analysis in animal health and reproduction: Methods and applications. J. Dairy Sci. 92:3545-3565.

Lock, A. L., C. Tyburczy, D. A. Dwyer, K. J. Harvatine, F. Destaillats, M. Mouloungui, L. Candy, and D. E. Bauman. 2007. Trans-10 octadecenoic acid does not reduce milk fat synthesis in dairy cows. J. Nutr. 137:71-76.

Lubis, D., H. H. Van Horn, B. Harris, K. C. Bachman, and S. M. Emanuele. 1990. Responses of lactating dairy cows to protected fats or whole cottonseed in low or high forage diets. J. Dairy Sci. 73:3512-3525.

Maiga, H. A., and D. J. Schingoethe. 1997. Optimizing the utilization of animal fat and ruminal bypass proteins in the diets of lactating dairy cows. J. Dairy Sci. 80:343-352.

Maiga, H. A., D. J. Schingoethe, and F. C. Ludens. 1995. Evaluation of diets containing supplemental fat with different sources of carbohydrates for lactating dairy cows. J. Dairy Sci. 78:1122-1130.

Markus, S. B., K. M. Wittenberg, J. R. Ingalls, and M. Undi. 1996. Production responses by early lactation cows to whole sunflower seed or tallow supplementation of a diet based on barley. J. Dairy Sci. 79:1817-1825.

Moate, P. J., W. Chalupa, R. C. Boston, and I. J. Lean. 2008. Milk fatty acids. II: Prediction of the production of individual fatty acids in bovine milk. J. Dairy Sci. 91:1175-1188.

Onetti, S. G., and R. R. Grummer. 2004. Response of lactating cows to three supplemental fat sources as affected by forage in the diet and stage of lactation: A meta-analysis of literature. Anim. Feed Sci. Technol. 115:65-82.

Palmquist, D. L., and T. C. Jenkins. 1980. Fat in lactation rations: Review. J. Dairy Sci. 63:1-14

Pantoja, J., J. L. Firkins, and M. L. Eastridge. 1995. Site of digestion and milk production by cows fed fats differing in saturation, esterification, and chain length. J. Dairy Sci. 78:2247-2258.

Peters, J. L., A. J. Sutton, D. R. Jones, K. R. Abrams, and L. Rushton. 2008. Contour-enhanced meta-analysis funnel plots help distinguish publication bias from other causes of asymmetry. J. Clin. Epidemiol. 61:991-996.

Petit, H. V. 2002. Digestion, milk production, milk composition, and blood composition of dairy cows fed whole flaxseed. J. Dairy Sci. $85: 1482-1490$.

Pires, A. V., M. L. Eastridge, and J. L. Firkins. 1996. Roasted soybeans, blood meal, and tallow as sources of fat and ruminally undegradable protein in the diets of lactating cows. J. Dairy Sci. $79: 1603-1610$

Rabiee, A. R., I. J. Lean, M. A. Stevenson, and M. T. Socha. 2010. Effects of feeding organic trace minerals on milk production and reproductive performance in lactating dairy cows: A meta-analysis. J. Dairy Sci. 93:4239-4251.

Sanchez, J., I. Dohoo, J. Carrier, and L. DesCoteaux. 2004. A metaanalysis of the milk-production response after anthelmintic treatment in naturally infected adult dairy cows. Prev. Vet. Med. $63: 237-256$.

Schingoethe, D. J., D. P. Casper, C. Yang, D. J. Illg, J. L. Sommerfeldt, and C. R. Mueller. 1988. Lactational response to soybean meal, heated soybean meal, and extruded soybeans with ruminally protected methionine. J. Dairy Sci. 71:173-180. 
Schneider, P., D. Sklan, W. Chalupa, and D. S. Kronfeld. 1988. Feeding calcium salts of fatty acids to lactating cows. J. Dairy Sci. 71:2143-2150.

Shingfield, K. J., A. Sæbø, P. C. Sæbø, V. Toivonen, and J. M. Griinari. 2009. Effect of abomasal infusions of a mixture of octadecenoic acids on milk fat synthesis in lactating cows. J. Dairy Sci. 92:4317-4329

Simas, J. M., J. T. Huber, Z. Wu, K. H. Chen, S. C. Chan, C. B. Theurer, and R. S. Swingle. 1995. Influence of steam-flaked sorghum grain and supplemental fat on performance of dairy cows in early lactation. J. Dairy Sci. 78:1526-1533.

Sklan, D., E. Bogin, Y. Avidar, and S. Gur-Arie. 1989. Feeding calcium soaps of fatty acids to lactating cows: Effect on production, body condition and blood lipids. J. Dairy Res. 56:675-681.

Sklan, D., M. Kaim, U. Moallem, and Y. Folman. 1994. Effect of dietary calcium soaps on milk yield, body weight, reproductive hormones, and fertility in first parity and older cows. J. Dairy Sci. $77: 1652-1660$

Soyeurt, H., F. Dehareng, P. Mayeres, C. Bertozzi, and N. Gengler. 2008. Variation of delta 9-desaturase activity in dairy cattle. J. Dairy Sci. 91:3211-3224.

Spicer, L. J., R. K. Vernon, W. B. Tucker, R. P. Wettemann, J. F Hogue, and G. D. Adams. 1993. Effects of inert fat on energy balance, plasma concentrations of hormones, and reproduction in dairy cows. J. Dairy Sci. 76:2664-2673.

Storry, J. E. 1970. Reviews of the progress of dairy science: Ruminant metabolism in relation to the synthesis and secretion of milk fat. J. Dairy Res. 37:139-164.

Tackett, V. L., J. A. Bertrand, T. C. Jenkins, F. E. Pardue, and L. W. Grimes. 1996. Interaction of dietary fat and acid detergent fiber diets of lactating dairy cows. J. Dairy Sci. 79:270-275.

Thomas, J. W., and R. S. Emery. 1969. Additive nature of sodium bicarbonate and magnesium oxide on milk fat concentrations of milking cows fed restricted-roughage rations. J. Dairy Sci. 52:1762-1769.

Thompson, S. G., and J. P. T. Higgins. 2002. How should metaregression analyses be undertaken and interpreted? Stat. Med. 21:1559-1573.

Thompson, S. G., and S. J. Sharp. 1999. Explaining heterogeneity in meta-analysis: A comparison of the methods. Stat. Med. 18:26932708.

Weiss, W. P., and J. M. Pinos-Rodríguez. 2009. Production responses of dairy cows when fed supplemental fat in low- and high-forage diets. J. Dairy Sci. 92:6144-6155.

Wu, Z., and J. T. Huber. 1994. Relationship between dietary-fat supplementation and milk protein-concentration in lactating cows-A review. Livest. Prod. Sci. 39:141-155.

Wu, Z., J. T. Huber, S. C. Chan, J. M. Simas, K. H. Chen, J. G. Varela, F. Santos, C. Fontes, and P. Yu. 1994. Effect of source and amount of supplemental fat on lactation and digestion in cows. J. Dairy Sci. 77:1644-1651.

Wu, Z., J. T. Huber, F. T. Sleiman, J. M. Simas, K. H. Chen, S. C. Chan, and C. Fontes. 1993. Effect of three supplemental fat sources on lactation and digestion in dairy cows. J. Dairy Sci. $76: 3562-3570$

\section{APPENDIX}

\section{Standard Operation Procedures-Fat Project}

1. Each paper was read to ascertain it contained sufficient information on each of the following items, which are essential for compiling a ration in CPM-Dairy:

- Animal details

- Diet ingredients
- Type and amount of fat supplement fed

- Daily dry matter intake of ingredients described

- Composition of individual feed ingredients

- Management (i.e., grazing, feedlot, dry lot)

2 . The following information on animal, management, and environment were entered in CPMDairy for each diet. We noted which details were described in the paper and which assumptions were made.

- Lactation number

- Current age (mo)

- Current weight (kg)

- Mature weight $(\mathrm{kg})$

- Calf birth weight $(\mathrm{kg})$

- Days pregnant (d)

- Body condition score (1-5 scale)

- Milk production (L)

- Milk fat (\%)

- Days in milk

- Milk true protein (\%)

- Current temperature $\left({ }^{\circ} \mathrm{C}\right)$

- Current relative humidity (\%)

- Previous temperature $\left({ }^{\circ} \mathrm{C}\right)$

- Previous relative humidity $(\%)$

- Activity

- Distance walked (m)

3. Average days in milk were set as the mean for the period of the trial.

4. The feed ingredients described in the paper were selected from the CPM-Dairy Feedbank and the individual feed components were edited to the specifications as described.

5. The intake and composition of each feed ingredient was entered in CPM-Dairy as described in the paper. Fatty acid profiles of the different feeds were entered when they were described in the respective papers. Where commercial feed additives were used and were not found in the CPM-Dairy library, they were searched for on the internet so their components could be entered into the program.

6. The CPM-Dairy output of the diet was compared with the diet composition described in the paper. Where significant differences were found, we evaluated which feeds would most likely be responsible for the differences found and each of these feed components was edited accordingly.

7. In general, it was determined that the forages would be the cause of most discrepancies between the model and the composition of the diet described in the paper because of the greater variation in nutrient value in these feeds. 
8. When no information was given, we assumed that the specifications on concentrates, protein meals, and fat contents were similar to those found in the CPM-Dairy Feedbank.

9. The CPM-Dairy outputs were entered into an Excel spreadsheet.

10. All nutrient specifications for the ingredients and fat supplements used were recorded and any assumptions made on the individual feeds were highlighted in the spreadsheet.

11. A summary of all animal, management, and environment details used for each diet was entered in a spreadsheet and any assumptions made were highlighted. 
¿ Table A1. Estimated adjusted (Adj.) and unadjusted (Unadj.) probabilities of meta-regression analysis of CPM-Dairy outputs using the simulation methods described by Higgins and Thompson (2004); variables with $P \leq 0.20$ (bold) were considered in the multivariate model

Probability ( $P$-value)

Estimated ME balance (MJ/cow/d)

Estimated MP balance $(\mathrm{g} / \mathrm{cow} / \mathrm{d})$

Bacterial MP (\% of MP)

CP (\% of diet)

CP eaten $(\mathrm{kg} / \mathrm{cow} / \mathrm{d})$

RUP (\% of CP)

RUP eaten $(\mathrm{kg} / \mathrm{cow} / \mathrm{d})$

$\mathrm{RDP}$ (\% of $\mathrm{CP}$ )

RDP eaten $(\mathrm{kg} / \mathrm{cow} / \mathrm{d})$

Soluble protein (\% of CP)

Soluble protein $(\mathrm{kg} / \mathrm{cow} / \mathrm{d})$

Urea cost (MJ/day)

Long-chain fatty acids (\% of diet)

Ether extract (\% of diet)

$\mathrm{NDF}$ (\% of diet)

NFC (\% of diet)

Sugar ( $\%$ of diet)

Starch (\% of diet)

Actual milk yield $(\mathrm{kg} / \mathrm{cow} / \mathrm{d})$

Actual milk yield true protein (\%)

Actual milk fat (\%)

Methionine (\% of requirement)

Lysine (\% of requirement)

Threonine (\% of requirement)

Leucine (\% of requirement)

Isoleucine (\% of requirement)

Valine (\% of requirement)

Histidine (\% of requirement)

Phenylalanine (\% of requirement)

Tryptophan (\% of requirement)

C12:0 intake $(\mathrm{g} / \mathrm{d})$

C16:0 intake (g/cow/d)

C16:1 intake (g/cow/d)

C18:0 intake (g/cow/d)

C18:1 trans intake $(\mathrm{g} / \mathrm{cow} / \mathrm{d})$

C18:1 cis intake $(\mathrm{g} / \mathrm{cow} / \mathrm{d})$

C18:2 intake $(\mathrm{g} / \mathrm{cow} / \mathrm{d})$

C18:3 intake ( $/$ cow/d)

Other fatty acids intake $(\mathrm{g} / \mathrm{cow} / \mathrm{d})$

C14:0 duodenum (g/cow/d)

C16:0 duodenum (g/cow/d)

C16:1 duodenum ( $\mathrm{g} / \mathrm{cow} / \mathrm{d})$

C18:0 duodenum (g/cow/d)

C18:1 trans duodenum $(\mathrm{g} / \mathrm{cow} / \mathrm{d})$

\begin{tabular}{|c|c|c|c|c|c|}
\hline \multicolumn{2}{|c|}{$\begin{array}{l}\text { Milk yield } \\
(\mathrm{kg} / \mathrm{cow} / \mathrm{d})\end{array}$} & \multicolumn{2}{|c|}{$\begin{array}{c}\text { DMI } \\
(\mathrm{kg} / \text { cow } / \mathrm{d})\end{array}$} & \multicolumn{2}{|c|}{$\begin{array}{c}\text { Fat percentage } \\
(\%)\end{array}$} \\
\hline Unadj. & Adj. & Unadj. & Adj. & Unadj. & Adj. \\
\hline 0.016 & 0.408 & & & 0.749 & 1.00 \\
\hline 0.435 & 1.000 & 0.004 & 0.069 & 0.159 & 0.98 \\
\hline 0.640 & 1.000 & 0.012 & 0.325 & 0.881 & 1.0 \\
\hline$<0.001$ & 0.164 & 0.304 & 0.998 & 0.003 & 0.1 \\
\hline 0.588 & 1.000 & 0.742 & 1.000 & 0.647 & 1.00 \\
\hline 0.013 & 0.402 & $<0.001$ & $<0.001$ & 0.924 & 1.00 \\
\hline 0.002 & 0.111 & 0.509 & 1.000 & 0.002 & 0.08 \\
\hline$<0.001$ & 0.063 & 0.003 & 0.085 & 0.050 & 0.744 \\
\hline 0.002 & 0.109 & 0.375 & 0.999 & 0.002 & 0.12 \\
\hline 0.993 & 1.000 & $<0.001$ & $<0.001$ & 0.029 & 0.597 \\
\hline 0.002 & 0.227 & 0.799 & 1.000 & 0.014 & 0.438 \\
\hline 0.381 & 1.000 & 0.001 & 0.044 & 0.059 & 0.810 \\
\hline 0.295 & 0.999 & 0.026 & 0.492 & 0.835 & 1.000 \\
\hline 0.297 & 1.000 & 0.118 & 0.969 & 0.007 & 0.329 \\
\hline 0.483 & 1.000 & 0.101 & 0.946 & 0.003 & 0.13 \\
\hline 0.100 & 0.897 & 0.850 & 1.000 & 0.453 & 1.000 \\
\hline 0.015 & 0.418 & 0.870 & 1.000 & 0.143 & 0.983 \\
\hline 0.054 & 0.823 & 0.362 & 0.999 & 0.041 & 0.734 \\
\hline 0.02 & 0.572 & 0.890 & 1.000 & 0.060 & 0.821 \\
\hline$<0.001$ & $<0.001$ & 0.007 & 0.261 & 0.004 & 0.17 \\
\hline 0.774 & 1.000 & 0.502 & 1.000 & $<0.001$ & $<0.00$ \\
\hline 0.093 & 0.932 & 0.426 & 1.000 & $<0.001$ & $<0.001$ \\
\hline 0.960 & 1.000 & 0.177 & 0.994 & 0.855 & 1.000 \\
\hline 0.805 & 1.000 & 0.027 & 0.500 & 0.793 & 1.000 \\
\hline 0.896 & 1.000 & 0.009 & 0.252 & 0.821 & 1.000 \\
\hline 0.443 & 1.000 & 0.039 & 0.719 & 0.774 & 1.000 \\
\hline 0.875 & 1.000 & 0.021 & 0.406 & 0.424 & 1.000 \\
\hline 0.743 & 1.000 & 0.007 & 0.226 & 0.345 & 1.000 \\
\hline 0.301 & 1.000 & 0.005 & 0.193 & 0.233 & 0.998 \\
\hline 0.413 & 1.000 & 0.004 & 0.204 & 0.309 & 1.000 \\
\hline 0.479 & 1.000 & 0.03 & 0.538 & 0.415 & 1.000 \\
\hline 0.291 & 1.000 & 0.873 & 1.000 & 0.615 & 1.000 \\
\hline 0.565 & 1.000 & 0.421 & 1.000 & 0.167 & 0.984 \\
\hline 0.605 & 1.000 & 0.814 & 1.000 & 0.638 & 1.000 \\
\hline 0.660 & 1.000 & 0.512 & 1.000 & 0.534 & 1.000 \\
\hline 0.454 & 1.000 & 0.991 & 1.000 & 0.561 & 1.000 \\
\hline 0.267 & 0.999 & 0.078 & 0.914 & 0.002 & 0.111 \\
\hline 0.942 & 1.000 & 0.117 & 0.968 & 0.004 & 0.19 \\
\hline 0.036 & 0.624 & 0.808 & 1.000 & 0.003 & 0.026 \\
\hline 0.993 & 1.000 & 0.381 & 1.000 & 0.493 & 1.000 \\
\hline 0.572 & 1.000 & 0.955 & 1.000 & 0.204 & 0.996 \\
\hline 0.609 & 1.000 & 0.353 & 0.999 & 0.214 & 0.994 \\
\hline 0.879 & 1.000 & 0.793 & 1.000 & 0.471 & 1.000 \\
\hline 0.533 & 1.000 & 0.901 & 1.000 & 0.028 & 0.578 \\
\hline 0.837 & 1.000 & 0.387 & 1.000 & 0.018 & 0.496 \\
\hline
\end{tabular}

$\frac{\begin{array}{c}\text { Fat yield } \\ (\mathrm{kg} / \text { cow } / \mathrm{d})\end{array}}{\text { Unadj. Adj. }}$

Protein
percentage (\%)

$<0.001$

$\mathbf{0 . 0 3 4}$
0.536

$\begin{array}{ll}0.034 & 0.709 \\ 0.536 & 1.000\end{array}$

$\begin{array}{ll}0.302 & 1.000\end{array}$

$\begin{array}{ll}0.302 & 1.000 \\ 0.289 & 1.000\end{array}$

$<0.001 \quad 0.024$

0.713

$\mathbf{0 . 0 3 0} 0.611$

$\begin{array}{ll}0.418 & 1.000 \\ \mathbf{0 . 0 0 6} & \mathbf{0 . 1 8 9}\end{array}$

$\mathbf{0 . 0 0 6} \mathbf{0 . 1 8 9}$

$\begin{array}{ll}0.985 & 1.000 \\ \mathbf{0 . 0 6 2} & 0.85\end{array}$

$\begin{array}{ll}0.910 & 1.000\end{array}$

$\mathbf{0 . 0 0 5} \quad 0.266$

$\mathbf{0 . 0 0 7} 0.336$

$0.332 \quad 1.000$

$0.500 \quad 1.000$

$\begin{array}{ll}0.515 & 1.000 \\ \mathbf{0 . 1 1 0} & 0.959\end{array}$

$\begin{array}{rr}\mathbf{0 . 1 1 0} & 0.959 \\ <\mathbf{0 . 0 0 1} & 0.002\end{array}$

$\mathbf{0 . 0 1 3} 0.408$

$<0.001<0.001$

$\begin{array}{rr}\mathbf{0 . 1 1 6} & 0.966\end{array}$

$0.416 \quad 1.000$

$0.299 \quad 1.000$

$\begin{array}{ll}0.505 & 1.000 \\ 0.352 & 1.000\end{array}$

$0.408 \quad 1.000$

$0.818 \quad 1.000$

$0.624 \quad 1.000$

$\begin{array}{ll}0.400 & 1.000 \\ 0.449 & 1.000\end{array}$

$\begin{array}{ll}0.449 & 1.000\end{array}$

$\begin{array}{ll}0.333 & 1.000 \\ 0.884 & 1.000\end{array}$

$\begin{array}{ll}0.969 & 1.000\end{array}$

$<0.001 \quad 0.009$

$\begin{array}{ll}0.770 & 1.000\end{array}$

$\begin{array}{ll}0.455 & 1.000 \\ 0.777 & 1.000\end{array}$

$0.744 \quad 0.999$

$\begin{array}{ll}0.244 & 0.999 \\ 0.583 & 1.000\end{array}$

$0.478 \quad 1.000$
0.489

$0.489 \quad 1.000$

$\begin{array}{ll}0.217 & 0.998 \\ 0.694 & 1.000\end{array}$

$\begin{array}{llll}0.501 & 1.000 & 0.001 & 0.032 \\ 0.721 & 1.000 & 0.59 & 1.000 \\ \mathbf{0 . 1 8 2} & 0.986 & 0.711 & 1.000 \\ \mathbf{0 . 0 0 8} & 0.212 & \mathbf{0 . 0 9 2} & 0.895 \\ \mathbf{0 . 0 7 5} & 0.837 & 0.487 & 1.000 \\ \mathbf{0 . 1 8 9} & 0.995 & \mathbf{0 . 0 0 2} & \mathbf{0 . 1 6 4} \\ \mathbf{0 . 0 0 6} & 0.247 & \mathbf{0 . 0 7 0} & 0.857 \\ \mathbf{0 . 0 0 9} & 0.258 & \mathbf{0 . 0 0 4} & 0.185 \\ \mathbf{0 . 0 1 6} & 0.451 & \mathbf{0 . 0 3 6} & 0.639 \\ 0.479 & 1.000 & \mathbf{0 . 1 4 6} & 0.991 \\ \mathbf{0 . 0 6 4} & 0.821 & \mathbf{0 . 0 2 7} & 0.679 \\ 0.345 & 1.000 & 0.992 & 1.000 \\ \mathbf{0 . 0 5 5} & 0.826 & \mathbf{0 . 1 4 1} & 0.977 \\ 0.596 & 1.000 & \mathbf{0 . 1 6 3} & 0.992 \\ 0.952 & 1.000 & 0.232 & 0.995 \\ 0.435 & 1.000 & 0.775 & 1.000 \\ 0.568 & 1.000 & 0.207 & 0.995 \\ \mathbf{0 . 1 5 9} & 0.991 & 0.548 & 1.000 \\ 0.734 & 1.000 & \mathbf{0 . 0 1 8} & 0.557 \\ \mathbf{0 . 0 6 4} & 0.844 & <\mathbf{0 . 0 0 1} & <\mathbf{0 . 0 0 1} \\ <\mathbf{0 . 0 0 1} & <\mathbf{0 . 0 0 1} & \mathbf{0 . 1 2 7} & 0.944 \\ \mathbf{0 . 0 5 8} & 0.784 & 0.480 & 1.000 \\ \mathbf{0 . 0 3 0} & 0.536 & 0.212 & 0.995 \\ \mathbf{0 . 0 4 9} & 0.682 & 0.248 & 0.997 \\ \mathbf{0 . 0 7 9} & 0.821 & \mathbf{0 . 1 1 9} & 0.960 \\ \mathbf{0 . 0 1 5} & 0.269 & 0.555 & 1.000 \\ \mathbf{0 . 0 0 2} & \mathbf{0 . 1 1 7} & 0.300 & 0.999 \\ \mathbf{0 . 0 0 2} & \mathbf{0 . 0 7 2} & 0.281 & 0.998 \\ \mathbf{0 . 0 0 4} & \mathbf{0 . 0 9 5} & 0.556 & 1.000 \\ \mathbf{0 . 0 0 2} & \mathbf{0 . 0 9 0} & 0.434 & 1.000 \\ \mathbf{0 . 0 4 4} & 0.660 & 0.206 & 0.995 \\ 0.553 & 1.000 & 0.828 & 1.000 \\ \mathbf{0 . 0 7 0} & 0.893 & 0.701 & 1.000 \\ \mathbf{0 . 0 0 9} & 0.236 & 0.927 & 1.000 \\ 0.944 & 1.000 & 0.741 & 1.000 \\ \mathbf{0 . 0 1 3} & 0.422 & 0.119 & 0.960 \\ 0.366 & 1.000 & 0.738 & 1.000 \\ \mathbf{0 . 1 5 2} & 0.982 & 0.396 & 1.000 \\ \mathbf{0 . 0 7 9} & 0.923 & 0.420 & 1.000 \\ \mathbf{0 . 1 0 7} & 0.961 & 0.218 & 0.995 \\ \mathbf{0 . 0 8 9} & 0.962 & 0.664 & 1.000 \\ \mathbf{0 . 0 0 7} & 0.230 & 0.932 & 1.000 \\ 0.639 & 1.000 & 0.865 & 1.000 \\ 0.590 & 1.000 & 0.677 & 1.000 \\ 0.854 & 1.000 & 0.459 & 1.000\end{array}$


Table A1 (Continued). Estimated adjusted (Adj.) and unadjusted (Unadj.) probabilities of meta-regression analysis of CPM-Dairy outputs using the simulation methods described by Higgins and Thompson (2004); variables with $P \leq 0.20$ (bold) were considered in the multivariate model

\begin{tabular}{|c|c|c|c|c|c|c|c|c|c|c|c|c|}
\hline \multirow[b]{3}{*}{ CPM-Dairy output } & \multicolumn{12}{|c|}{ Probability ( $P$-value $)$} \\
\hline & \multicolumn{2}{|c|}{$\begin{array}{l}\text { Milk yield } \\
(\mathrm{kg} / \mathrm{cow} / \mathrm{d})\end{array}$} & \multicolumn{2}{|c|}{$\begin{array}{c}\mathrm{DMI} \\
(\mathrm{kg} / \mathrm{cow} / \mathrm{d})\end{array}$} & \multicolumn{2}{|c|}{$\begin{array}{c}\text { Fat percentage } \\
(\%)\end{array}$} & \multicolumn{2}{|c|}{$\begin{array}{l}\text { Fat yield } \\
(\mathrm{kg} / \mathrm{cow} / \mathrm{d})\end{array}$} & \multicolumn{2}{|c|}{$\begin{array}{c}\text { Protein } \\
\text { percentage }(\%)\end{array}$} & \multicolumn{2}{|c|}{$\begin{array}{l}\text { Protein yield } \\
(\mathrm{kg} / \mathrm{cow} / \mathrm{d})\end{array}$} \\
\hline & Unadj. & Adj. & Unadj. & Adj. & Unadj. & Adj. & Unadj. & Adj. & Unadj. & Adj. & Unadj. & Adj. \\
\hline C18:1 cis duodenum (g/cow/d) & 0.838 & 1.000 & 0.121 & 0.975 & $<0.001$ & 0.097 & $<0.001$ & 0.016 & 0.092 & 0.908 & 0.313 & 0.999 \\
\hline C18:2 duodenum (g/cow/d) & 0.100 & 0.941 & 0.430 & 1.000 & $<0.001$ & $<0.001$ & 0.003 & 0.120 & 0.001 & 0.059 & 0.813 & 1.000 \\
\hline C18:3 duodenum (g/cow/d) & 0.085 & 0.867 & 0.270 & 0.998 & 0.005 & 0.028 & 0.038 & 0.386 & 0.075 & 0.812 & 0.861 & 1.000 \\
\hline $\begin{array}{l}\text { Total intake of fermented carbohydrate } \\
(\mathrm{kg} / \mathrm{cow} / \mathrm{d})\end{array}$ & 0.005 & 0.311 & $<0.001$ & $<0.001$ & 0.331 & 1.000 & 0.001 & 0.024 & 0.737 & 1.000 & $<0.001$ & 0.060 \\
\hline $\begin{array}{l}\text { Carbohydrate fermented NDF intake } \\
(\mathrm{kg} / \text { cow } / \mathrm{d})\end{array}$ & 0.812 & 1.000 & 0.001 & 0.059 & 0.094 & 0.905 & 0.014 & 0.442 & 0.446 & 1.000 & 0.550 & 1.000 \\
\hline $\begin{array}{l}\text { Carbohydrate fermented starch intake } \\
(\mathrm{kg} / \mathrm{cow} / \mathrm{d})\end{array}$ & 0.002 & 0.132 & 0.001 & 0.053 & 0.143 & 0.981 & 0.003 & 0.203 & 0.788 & 1.000 & $<0.001$ & 0.022 \\
\hline $\begin{array}{l}\text { Carbohydrate fermented soluble fiber } \\
\text { intake }(\mathrm{kg} / \mathrm{cow} / \mathrm{d})\end{array}$ & 0.927 & 1.000 & 0.001 & 0.011 & 0.345 & 1.000 & 0.958 & 1.000 & 0.882 & 1.000 & 0.948 & 1.000 \\
\hline $\begin{array}{l}\text { Carbohydrate fermented sugar intake } \\
(\mathrm{kg} / \mathrm{cow} / \mathrm{d})\end{array}$ & 0.028 & 0.535 & 0.001 & 0.033 & 0.022 & 0.647 & 0.281 & 1.000 & 0.100 & 0.937 & 0.125 & 0.95 \\
\hline $\mathrm{Mg}(\%$ of DMI) & 0.210 & 0.996 & 0.947 & 1.000 & 0.046 & 0.716 & 0.457 & 1.000 & 0.056 & 0.672 & 0.030 & 0.587 \\
\hline
\end{tabular}

